\title{
A WALK THROUGH THE MCLOUD HIGH SCHOOL OAK-HICKORY FOREST WITH A CHECKLIST OF THE WOODY PLANTS
}

\author{
Bruce A. Smith \\ McLoud High School \\ 1100 West Seikel \\ McLoud, OK 74851 \\ brucesmith@mcloudschools.us
}

\begin{abstract}
The McLoud High School oak-hickory forest is located a short distance from the McLoud High School campus. The forest has been used as an outdoor classroom for many years for high school students. This article will guide you through the forest trail and discuss several woody plants of interest at 16 landmarks. The article also includes a checklist of the 38 woody species identified in the forest.
\end{abstract}

Key words: woody plants, checklist, invasive plants, hybridization, leafcurl

\section{INTRODUCTION}

The McLoud High School forest has been an important element in my teaching career for many years. I can't remember the first time that we started using the McLoud oak-hickory forest as an outdoor classroom. I do remember Kari Courkamp doing research on tree lichens 25 years ago. Since that time there was a long period when we used it mostly to learn about the composition and structure of the forest. In the last few years, we have done a variety of projects including aging the bigger trees, bark studies, journaling, fungi hunts, creating a marked trail, and general ecology. The forest is a small oak-hickory forest just a short walk from the main high school campus. The forest is dominated by post oak (Quercus stellata), blackjack oak ( $Q$. marilandica), and black hickory (Carya texana). In this article I will walk you through 16 sites along the forest trail. At each landmark I will discuss some of the woody plants that can be seen at that particular site. The article will also include a checklist of woody plants we have seen in the forest. Unless otherwise indicated, all photos were taken by McLoud High School Botany classes over a number of years.

\section{STUDY AREA}

The forest is about $100 \mathrm{~m} \mathrm{(330} \mathrm{ft)} \mathrm{by}$ $76 \mathrm{~m}(250 \mathrm{ft})$ and is located near the McLoud High School campus in McLoud, Oklahoma. It is bordered by adjacent forests on the south and east. The forest has been utilized as an outdoor classroom for the high school students for many years. Observations by students include not only species present but also the condition of the plants and plant-animal interactions, such as insects causing leaves to curl (Figure 1).

\section{RESULTS}

Table 1 below summarizes the woody flora that we have recorded for the McLoud oak-hickory forest. We have identified 38 species in 31 genera and 24 families. The forest canopy is dominated by post oak, blackjack oak, and black hickory. Understory species include red mulberry 
(Morus rubra) and hackberry (Celtis spp.). Common shrubs and vines include coralberry (Symphoricarpos orbiculatus), roughleaf dogwood (Cornus drummondii), greenbrier (Smilax sp.), and blackberry (Rubus sp.).

Table 1 Summary of the woody taxa in the McLoud High School oak-hickory forest

\begin{tabular}{|c|c|}
\hline $\begin{array}{c}\text { TAXONOMIC } \\
\text { CATEGORIES }\end{array}$ & $\begin{array}{c}\text { TOTAL TAXA IN } \\
\text { THE CATEGORY }\end{array}$ \\
\hline FAMILIES & 24 \\
\hline GENERA & 31 \\
\hline SPECIES & 38 \\
\hline
\end{tabular}

\section{LITERATURE CITED}

Integrated Taxonomic Information System (ITIS). 2020. http://www.itis.gov

(March 20, 2020)

USDA NRCS. 2020. The PLANTS

Database. http://plants.usda.gov

(April 11, 2020)

\section{ACKNOWLEDGMENTS}

I want to say thank you to both the reviewers and editorial committee. A special thanks to Gloria Caddell; your patience is amazing. Finally, thanks to the McLoud High School Botany classes throughout the years for all the keen observations and project work.

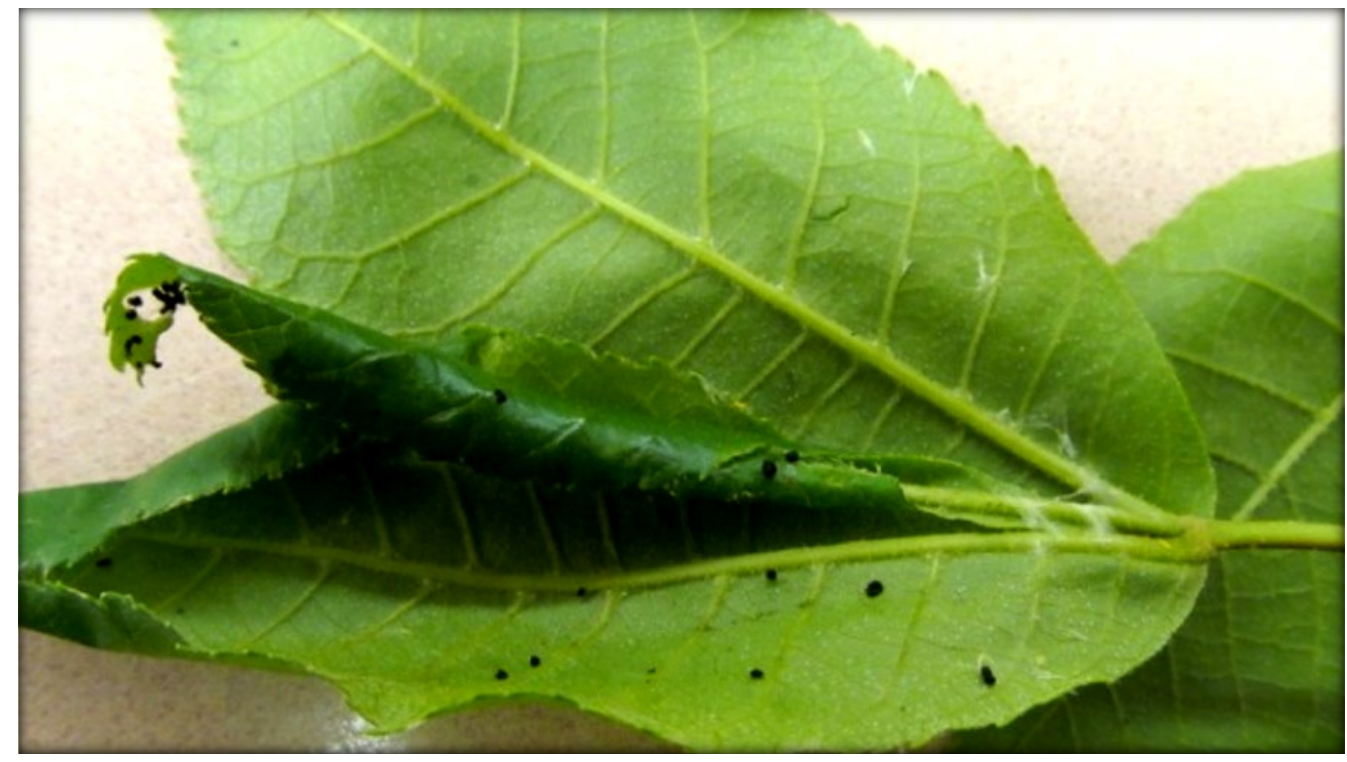

Figure 1 Terminal leaflet curl. The curling may be a response to some type of larva. Forest observations are potential student projects. Each time we visit the forest, new questions are asked — creating new student projects. 


\section{CHECKLIST OF THE WOODY PLANTS OF THE MCLOUD OAK-HICKORY FOREST}

Taxa introduced to North America are indicated with an asterisk (*). Nomenclature is based on ITIS (2020). Common names are from the USDA PLANTS Database (USDA NRCS 2020), although in a few cases a common name more widely used in Oklahoma is added.

\section{ADOXACEAE}

Viburnum rufidulum Raf., rusty blackhaw (Figure 2)

\section{ANACARDIACEAE}

Rhus copallinum $L$., winged sumac

Rhus glabra L., smooth sumac (Figure 3)

Toxicodendron rydbergii (Small ex Rydb.) J. Greene, western poison ivy

\section{AQUIFOLIACEAE}

Ilex vomitoria Aiton, yaupon

\section{BIGNONIACEAE}

Campsis radicans (L.) Seem. ex Bureau, trumpet creeper (Figure 4)

\section{CACTACEAE}

Opuntia humifusa (Raf.) Raf., devil's-tongue, pricklypear cactus

\section{CAPRIFOLIACEAE}

*Lonicera japonica Thunb., Japanese honeysuckle

Symphoricarpos orbiculatus Moench, coralberry

\section{CELTIDACEAE}

Celtis laevigata Willd., sugarberry

Celtis occidentalis L., common hackberry

Celtis reticulata Torr., netleaf hackberry

\section{CORNACEAE}

Cornus drummondii C. A. Mey., roughleaf dogwood

\section{CUPRESSACEAE}

Juniperus virginiana L., eastern redcedar

\section{EBENACEAE}

Diospyros virginiana L., common persimmon

\section{FABACEAE}

Cercis canadensis L., eastern redbud

\section{FAGACEAE}

Quercus marilandica Münchh., blackjack oak (Figure 5)

Quercus muehlenbergii Engelm., chinquapin oak (Figure 6) 
Quercus stellata Wangenh., post oak

Quercus velutina Lam., black oak

JUGLANDACEAE

Carya texana Buckley, black hickory

\section{MENISPERMACEAE}

Cocculus carolinus (L.) DC., Carolina coralbead, Carolina snailseed

\section{MORACEAE}

Morus rubra L. red mulberry

\section{OLEACEAE}

*Ligustrum sinense Lour., Chinese privet

\section{ROSACEAE}

Crataegus L. sp., hawthorn

Prunus mexicana S. Watson, Mexican plum

${ }^{*}$ Rosa multiflora Thunb., multiflora rose

Rubus L. sp., blackberry

\section{RUTACEAE}

Zanthoxylum americanum Mill., common pricklyash

\section{SALICACEAE}

Populus deltoides W. Bartram ex Marshall, eastern cottonwood

\section{SAPINDACEAE}

Sapindus saponaria var. drummondii (Hook. \& Arn.) L. D. Benson (=Sapindus drummondii Hook. \& Arn.), western soapberry

\section{SAPOTACEAE}

Sideroxylon lanuginosum Michx. (=Bumelia lanuginosa [Michx.]Pers.), gum bully, chittamwood

\section{SMILACACEAE}

Smilax L. sp., greenbrier

\section{ULMACEAE}

Ulmus americana L., American elm

Ulmus rubra Muhl., slippery elm, red elm

\section{VITACEAE}

Ampelopsis arborea (L.) Koehne, peppervine

Parthenocissus quinquefolia (L.) Planch., Virginia creeper

Vitis L. sp., grape (Figure 7) 


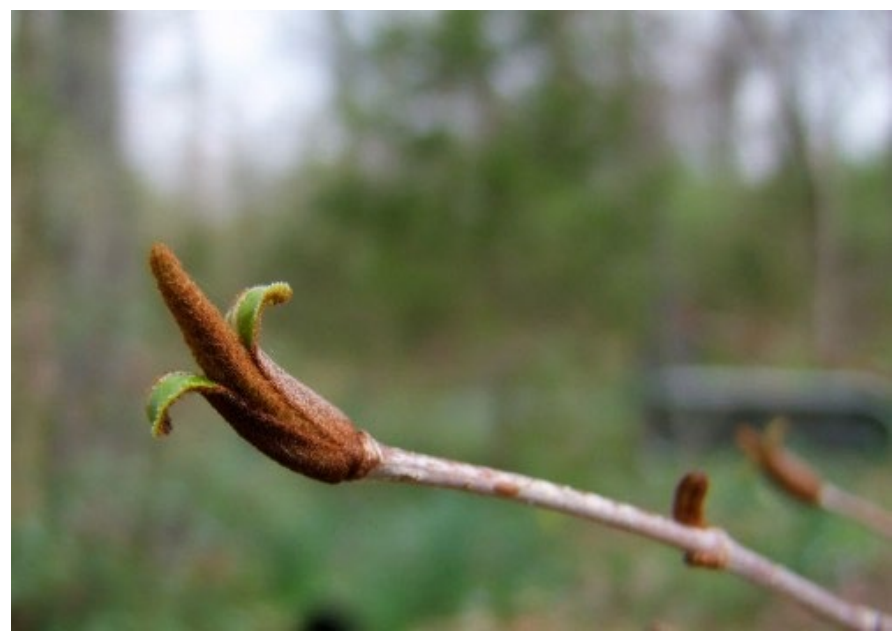

Figure 2 Rusty blackhaw, Viburnum rufidulum, bud in late winter or early spring

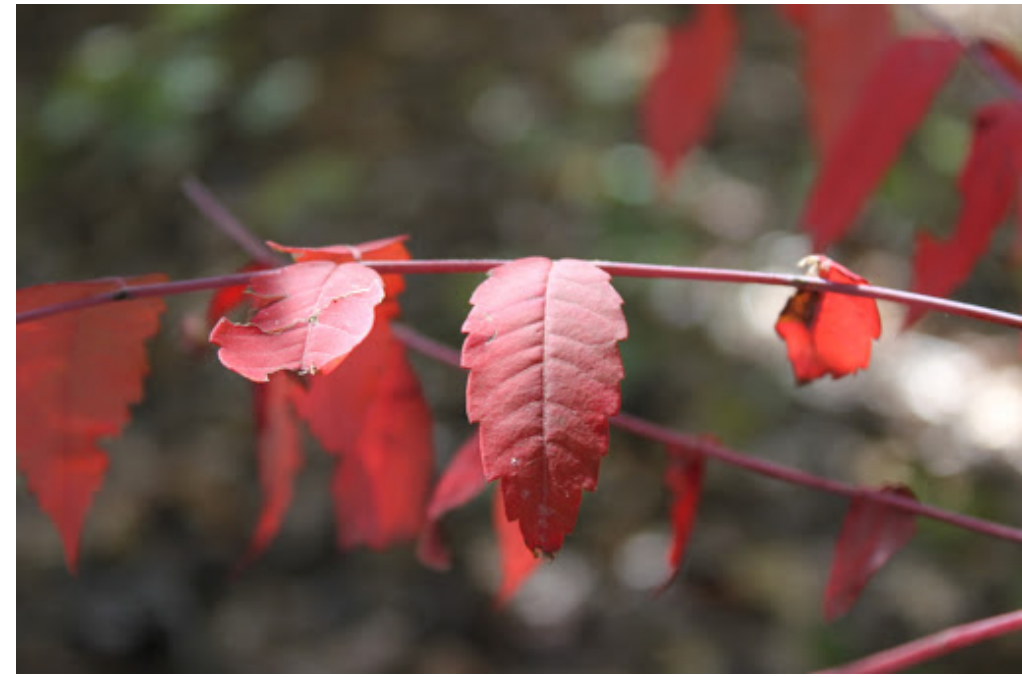

Figure 3 Smooth sumac, Rhus glabra. Photo by Emily Miller.

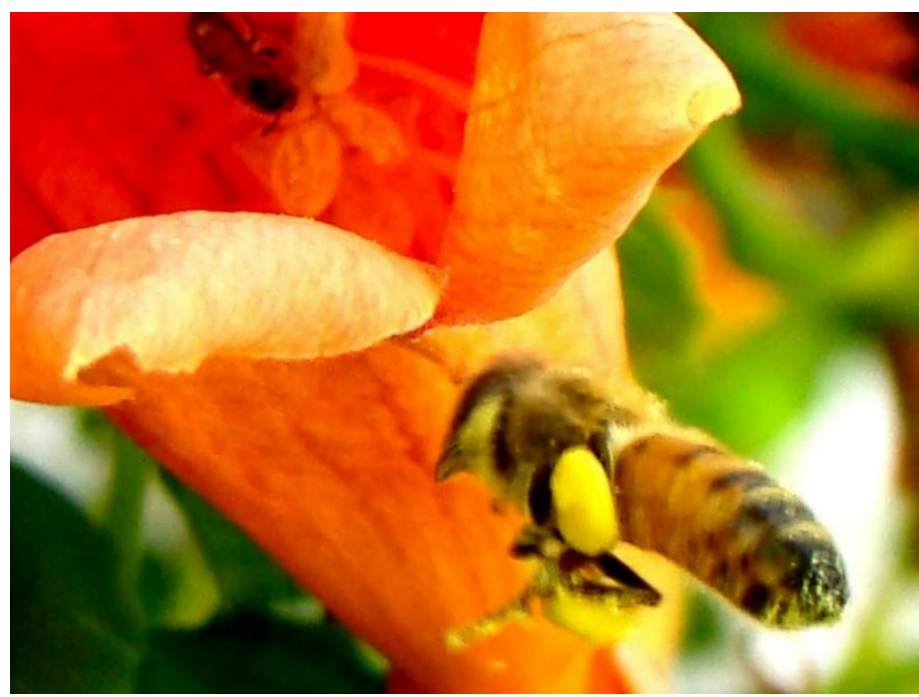

Figure 4 Trumpet creeper, Campsis radicans 


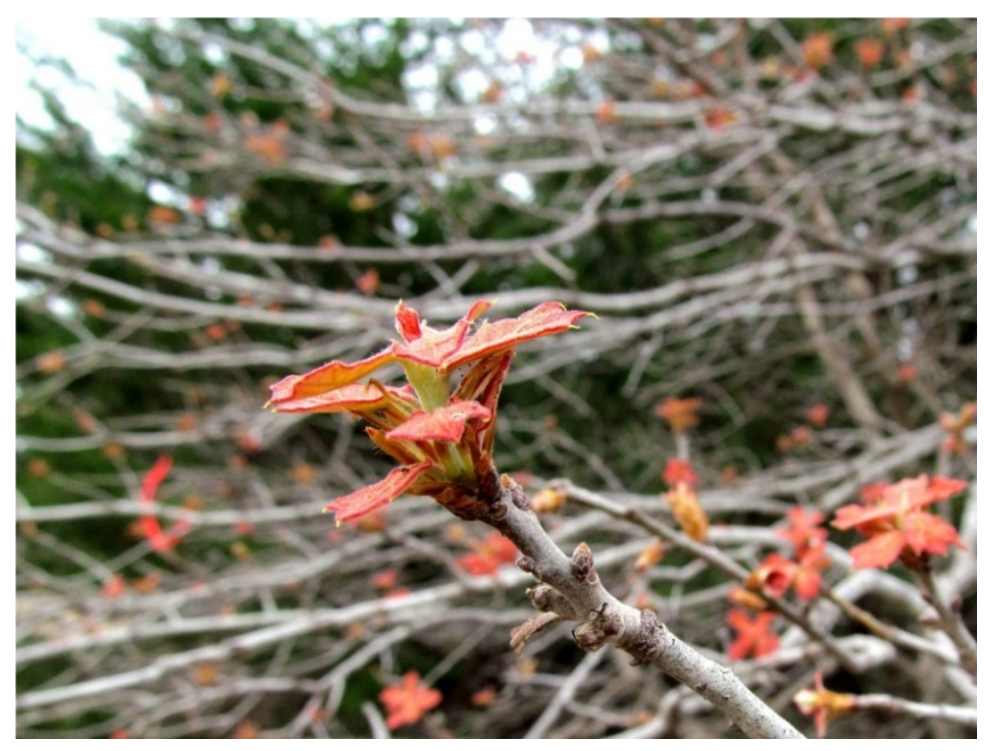

Figure 5 Quercus marilandica, blackjack oak, in late winter or early spring

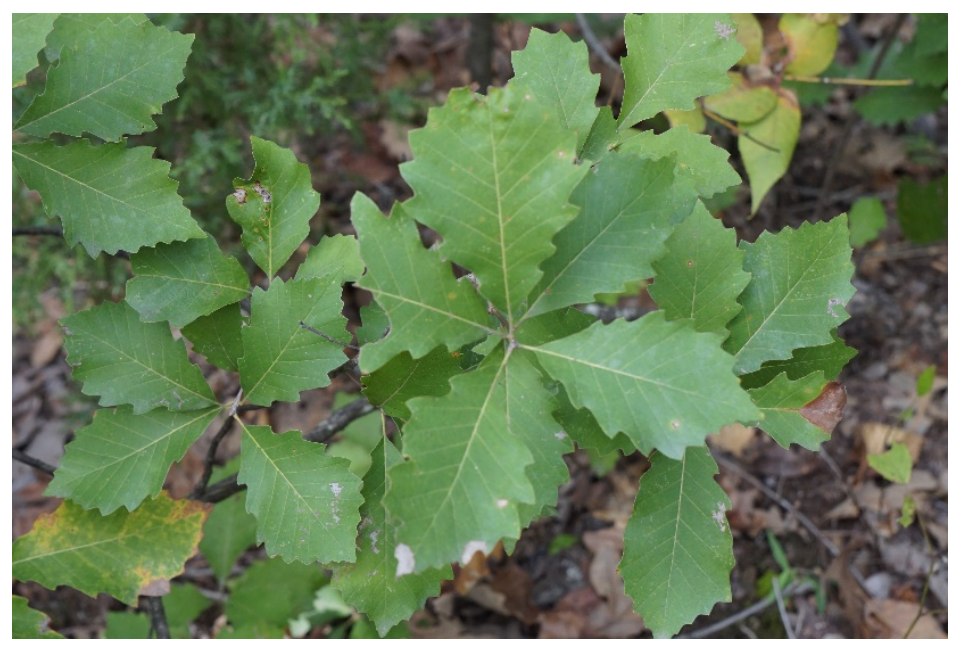

Figure 6 Chinquapin oak, Quercus mueblenbergii

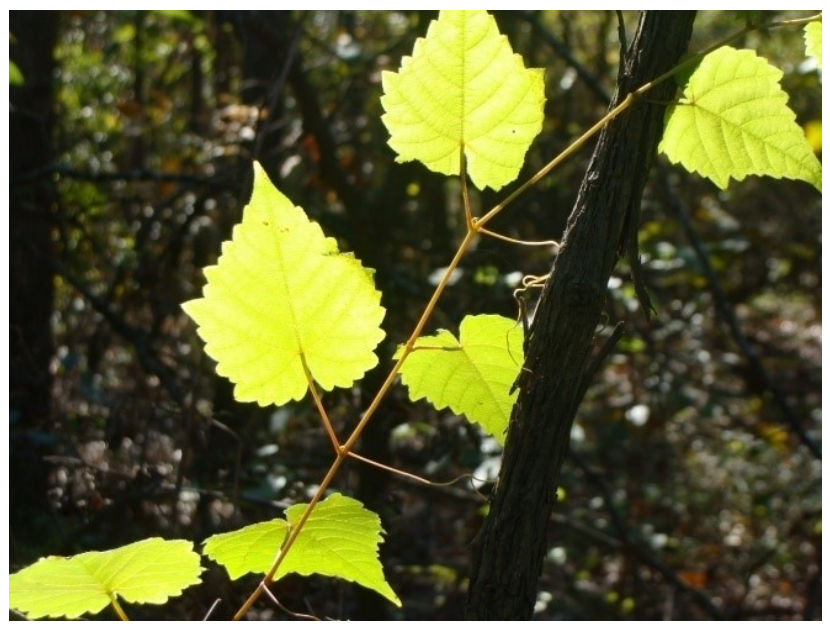

Figure 7 Grape vine, Vitis sp. 


\section{A TRAIL TOUR THROUGH THE MCLOUD HIGH SCHOOL OAK-HICKORY FOREST}

Welcome to the McLoud High School oak-hickory forest. As I guide you through the forest trail, you will need to refer to the trail map (Figure 8) with the 16 marked sites. The trees and shrubs you see at each site are briefly described and easy to find near each marked area. Walking the trail and visiting each site should not take long; better yet, take your time and enjoy the diversity each site offers. The best times to visit the forest are the last two weeks of April and the first two weeks of October. As you walk the trail, look for lichens on tree branches (Figure 9). Many years ago, Kari Courkamp studied lichens in this forest, and this article is dedicated to her.

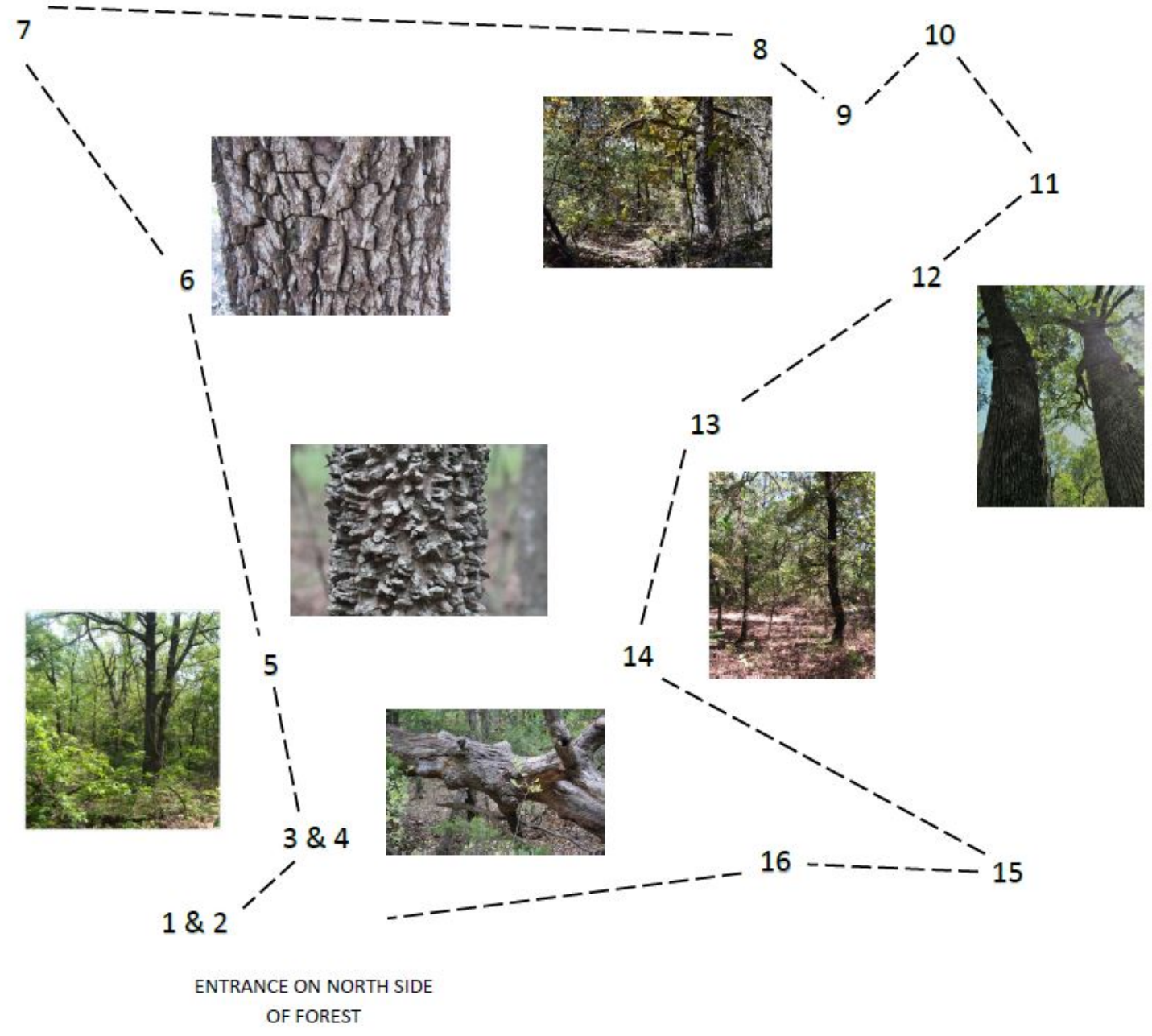

Figure 8 McLoud High School oak-history forest trail map 


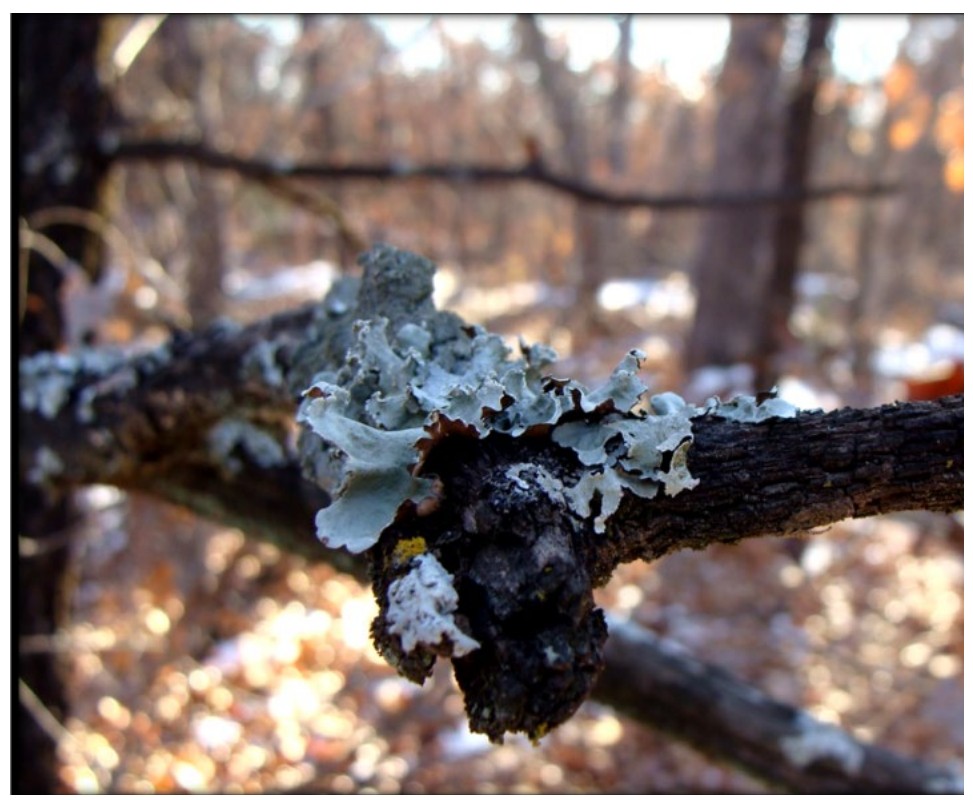

Figure 9 Foliose lichens on a tree branch

Landmarks 1, 2. As you enter the forest (Figure 10), about five meters from the entrance there is a small population of prickly pear cacti or devil's-tongue, Opuntia bumifusa

(Figure 11). Don't be surprised; prickly pear cacti are more common in forests than you might think. As you continue on the trail, look for a red elm, Ulmus rubra, on the left side (Figure 12). Table 2 gives characteristics that can be used to distinguish it from the other elm (U. americana) in this forest.

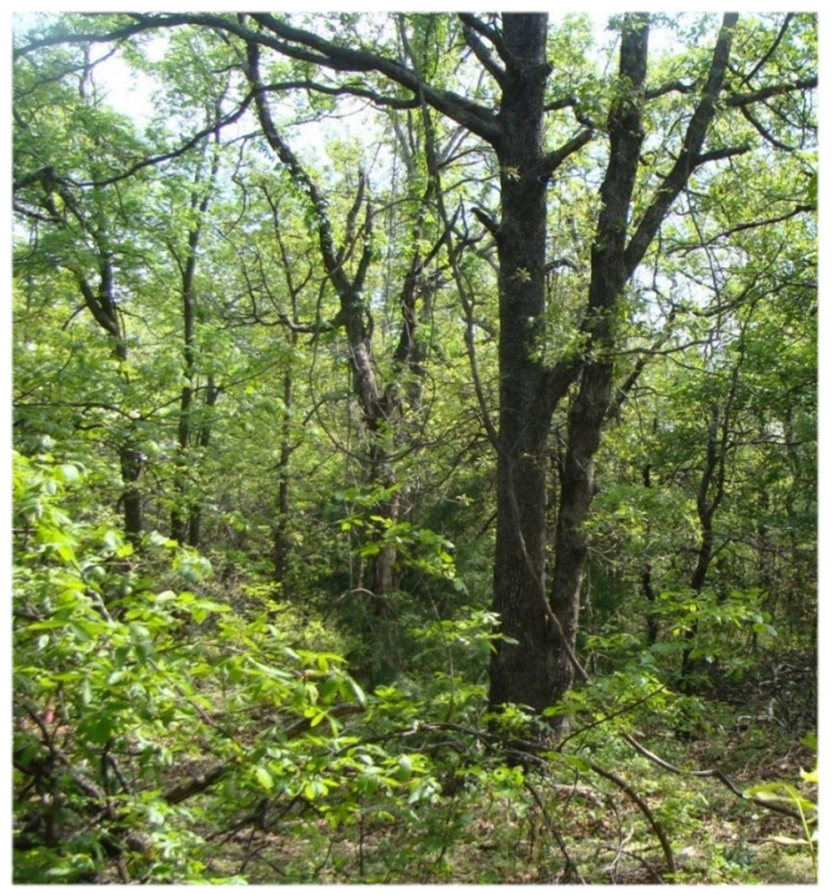

Figure 10 Small opening in the forest near the north side entrance

Table 2 Comparing the axillary buds and adaxial (upper) blade surfaces of the two elms in the forest

\begin{tabular}{|l|l|l|}
\hline Species & Axillary buds & Adaxial blade surfaces \\
\hline Ulmus rubra & with red hairs & scabrous \\
\hline Ulmus americana & glabrous & glabrous \\
\hline
\end{tabular}




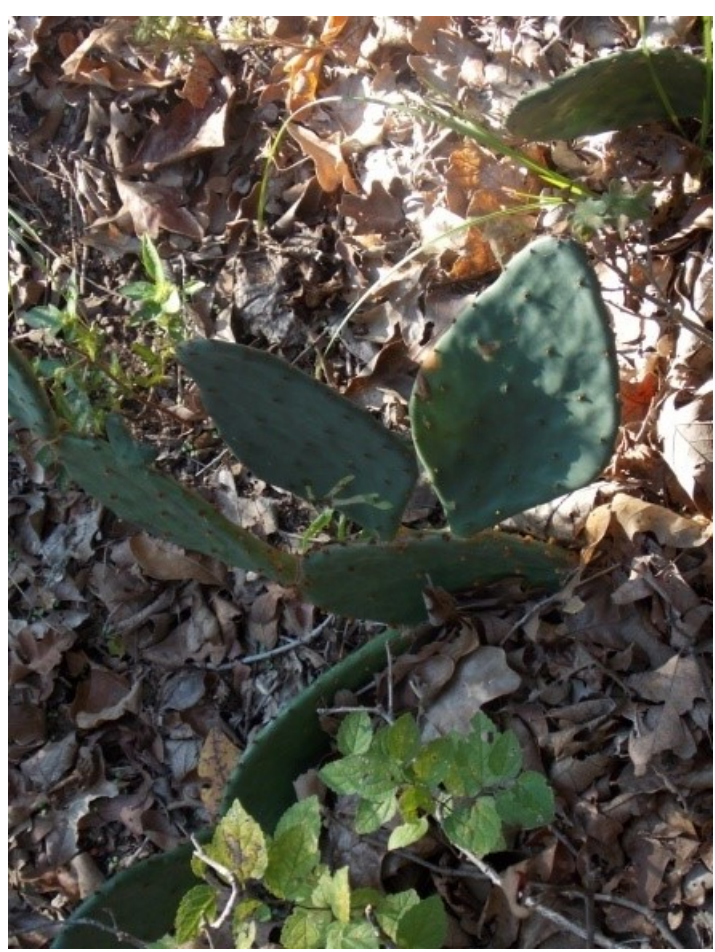

Figure 11 Opuntia humifusa, devil's tongue prickly pear cactus

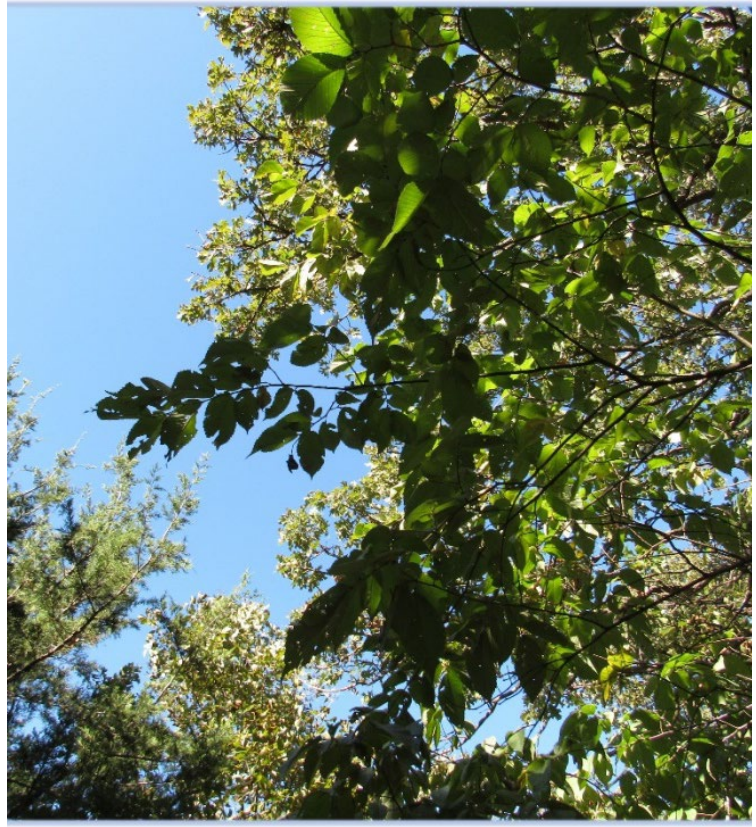

Figure 12 Red elm (or slippery elm), Ulmus rubra. This is one of the two elm species we have in the forest. Red elm can be distinguished from American elm by its axillary buds and leaf blade surfaces (See Table 2). DBH $=7.0 \mathrm{~cm}$

Landmarks 3, 4. Dead post oak, Quercus stellata. This dead tree (Figure 13) has been a good reference point for the forest trail for many years. It has recently collapsed. On the opposite side of the collapsed tree is a showy shrub known as rusty blackhaw, Viburnum rufidulum (Figure 14). If you visit in April, you are likely to see the rusty blackhaw in flower.

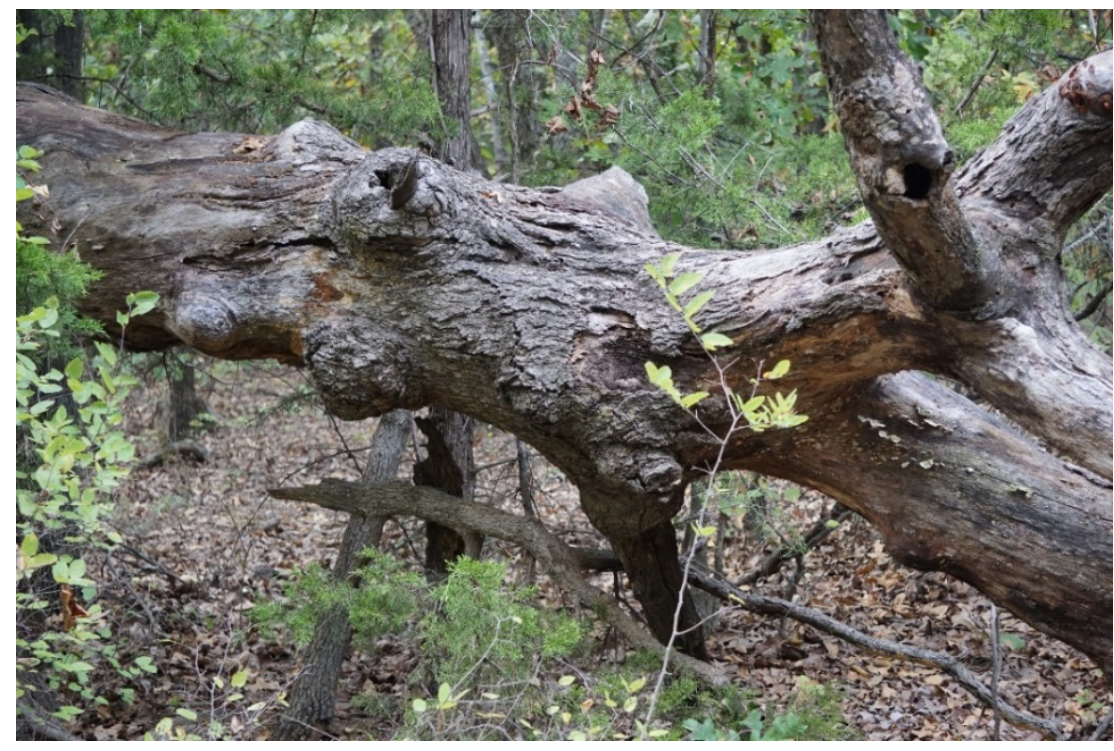

Figure 13 Dead post oak tree near the entrance to the forest 


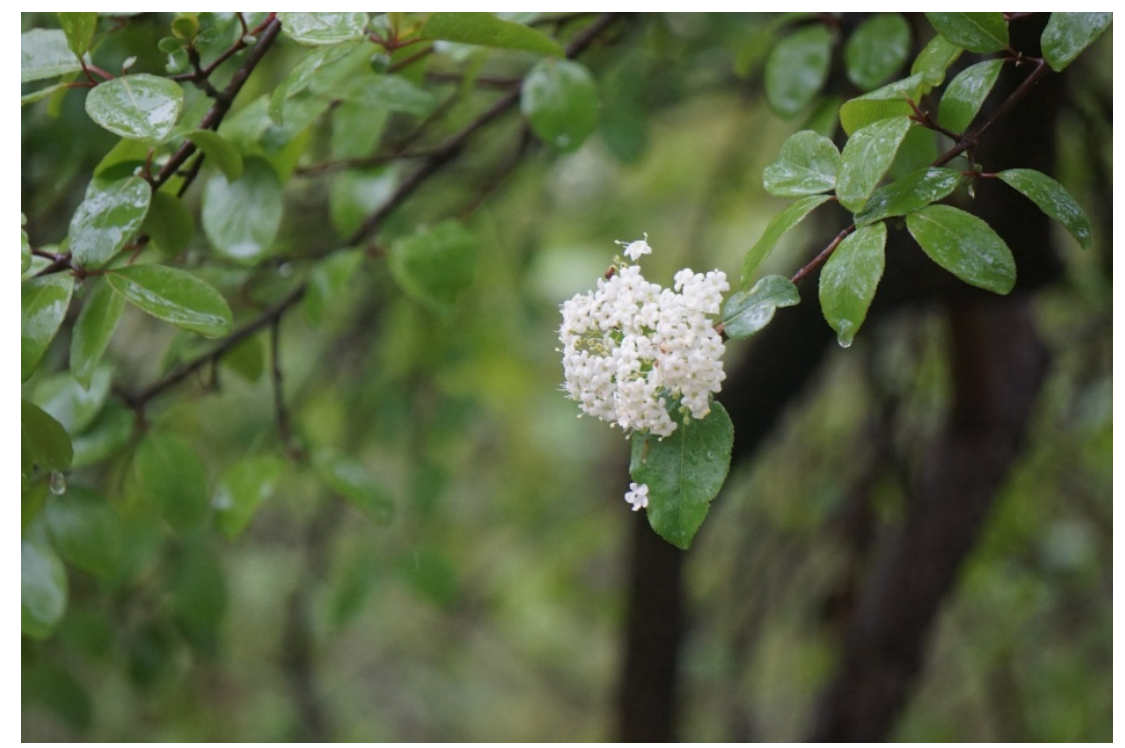

Figure 14 Rusty blackhaw, Viburnum rufidulum. The forest includes several individual shrubs of rusty blackhaw. Look for the rusty red color at the leaf petiole base. Photo by Bruce Smith; probably taken at Falls Creek.

Landmark 5. Hackberry population. Hackberry and sugarberry can be easily identified to the genus Celtis by their corky-warty bark (Figure 15) and pinni-palmate leaf veins (Figure 16).

Identifying the trees to Celtis is not a problem, but identifying species is a real challenge due to hybridization in the genus. We will recognize three species of Celtis in the forest. Celtis laevigata, sugarberry, is the most conspicuous (Figure 17). In general, C. laevigata separates itself from the other species by having leaves about 3 times longer than wide compared to the other two likely species that are about 1.5 times longer than wide (Figure 18).

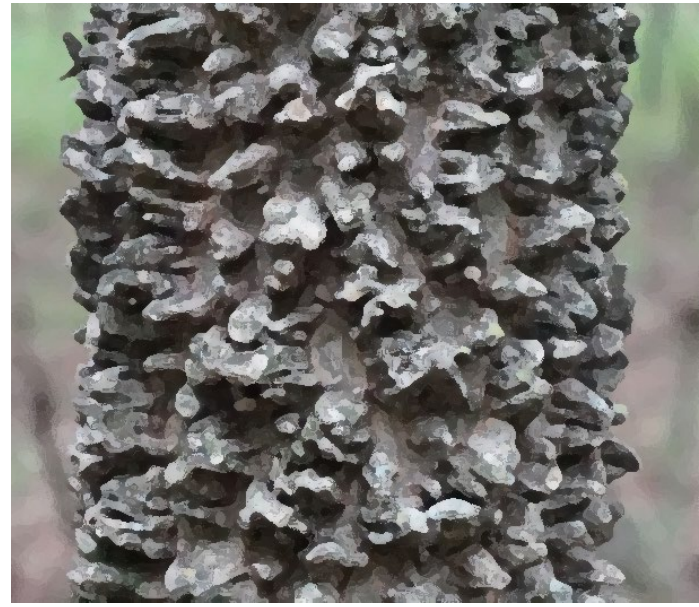

Figure 15 Warty-corky bark, genus Celtis. Photo taken by Bruce Smith at Green Leaf State Park.

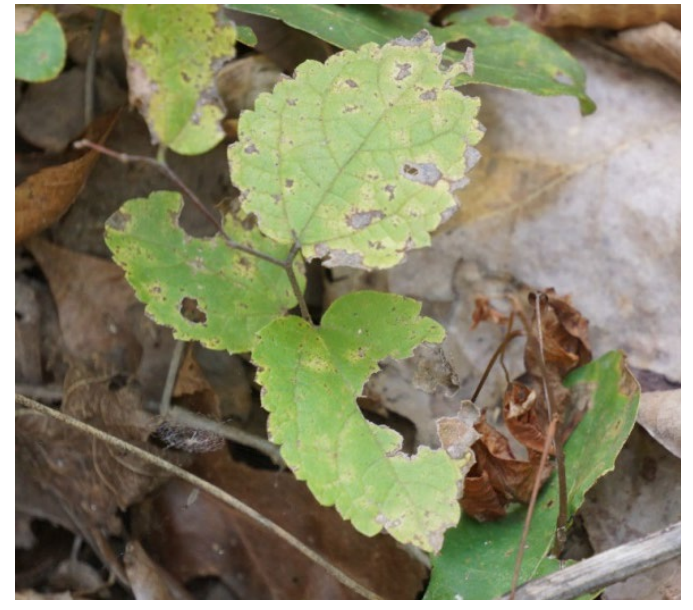

Figure 16 Unknown species of the genus Celtis. 


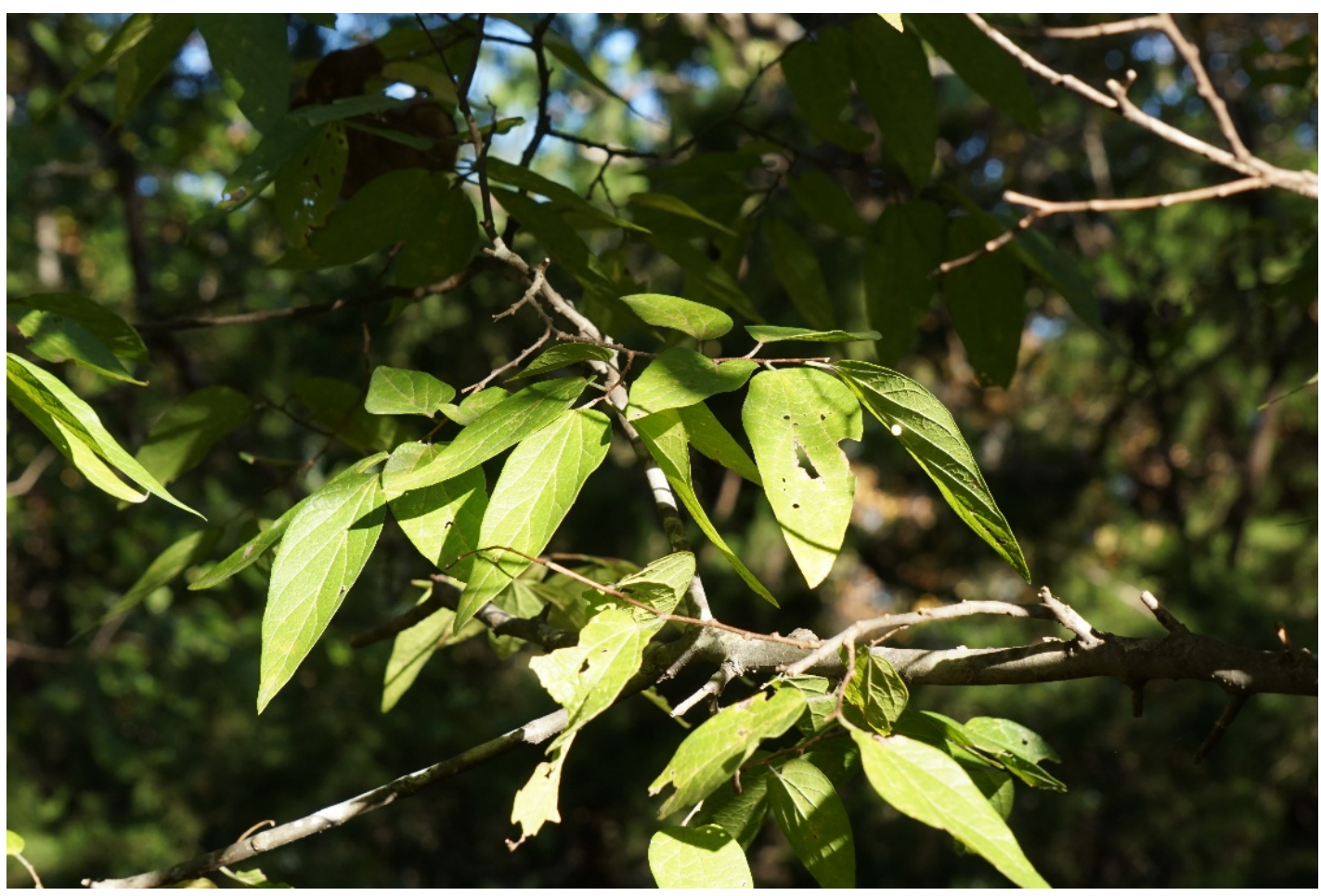

Figure 17 Sugarberry, Celtis laevigata. Note the leaves that are about three times longer than wide and the falcate apices.

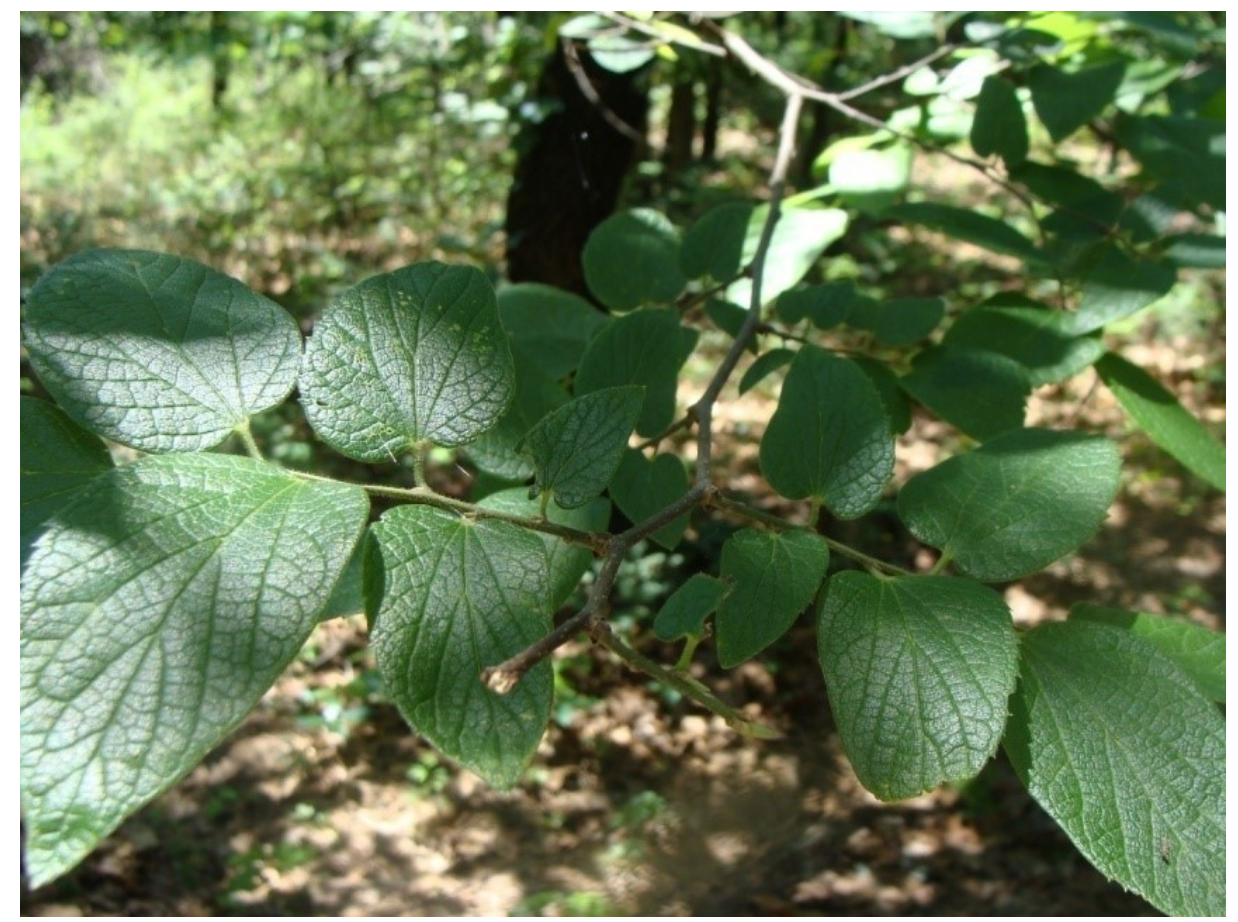

Figure 18. Celtis reticulata, the netleaf hackberry. Note the prominent veins and thick leaves. 
Landmark 6. Big hickory forest, Carya texana. This area of the forest has four large black hickory trees. Each tree is about the same diameter $(50 \mathrm{~cm}$ at breast height). Black hickory can be easily identified by its heart-shaped leaf scars (Figure 19), alternate compound leaves, and dark chunky bark on the older trees. In Figure 20, note the chunky black bark with straight lines at the base of the "chunks".

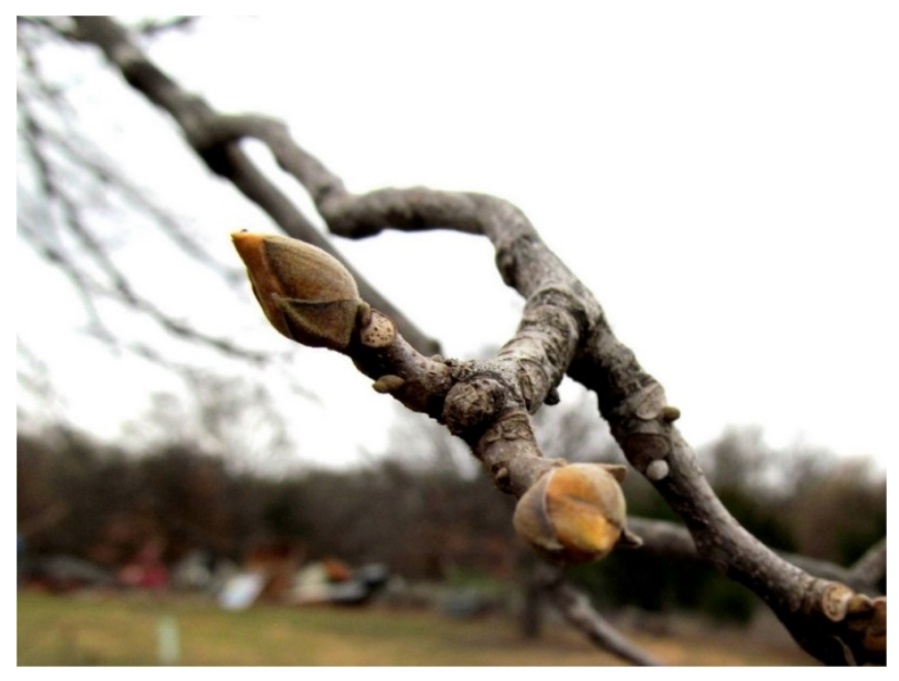

Figure 19 Terminal buds of a young black hickory tree. You might be able to see the heart-shaped leaf scars. Imagine the buds before you bearing three to five pinnately compound leaves. Spring is on its way.

Figure 20 Bark of the larger black hickory trees in the forest. The density of black hickories in the forest is relatively high. Most of them are young trees. The bark of the younger trees is gray and smooth with gray crustose lichens.

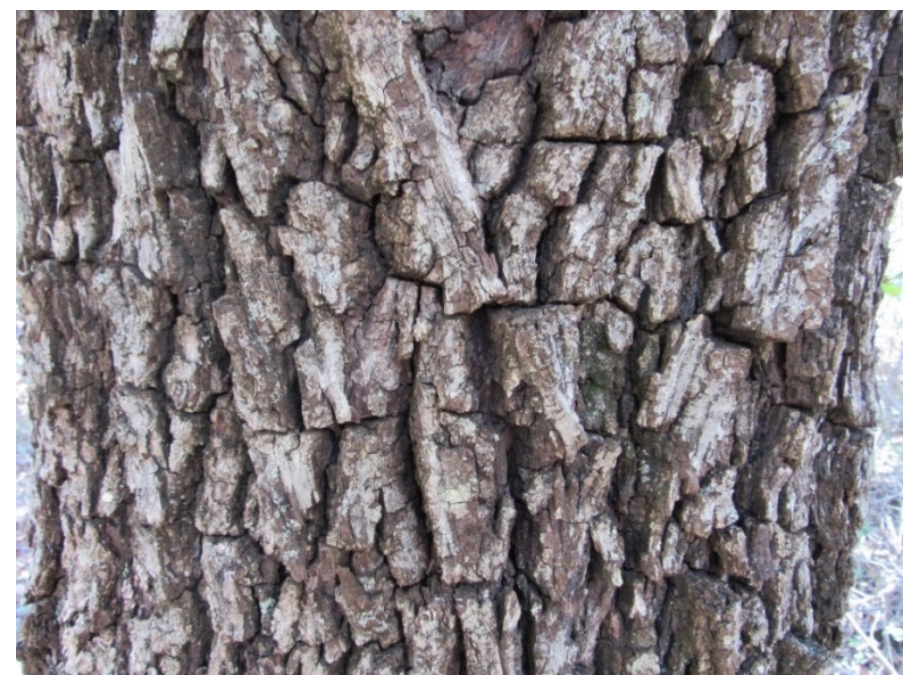

Landmark 7. Dead cottonwood, Populus deltoides. In the southeast corner of the forest, there is a cottonwood tree that has recently died. This species really does not fit the dry upland habitat; thus, it provides a good opportunity for teachers to discuss cottonwood ecology with their students. Walking along the south boundary fence you should see several large straight stems. These straight stems are roughleaf dogwoods, Cornus drummondii. These shrubs are the first to leaf out in early spring, getting an early start on photosynthesis. During the growing season they are easily identified by their simple opposite leaves and straight stems (Figure 21). Depending on the season, you might also see various herbaceous plants such as brown-eyed susan (Figure 22). 


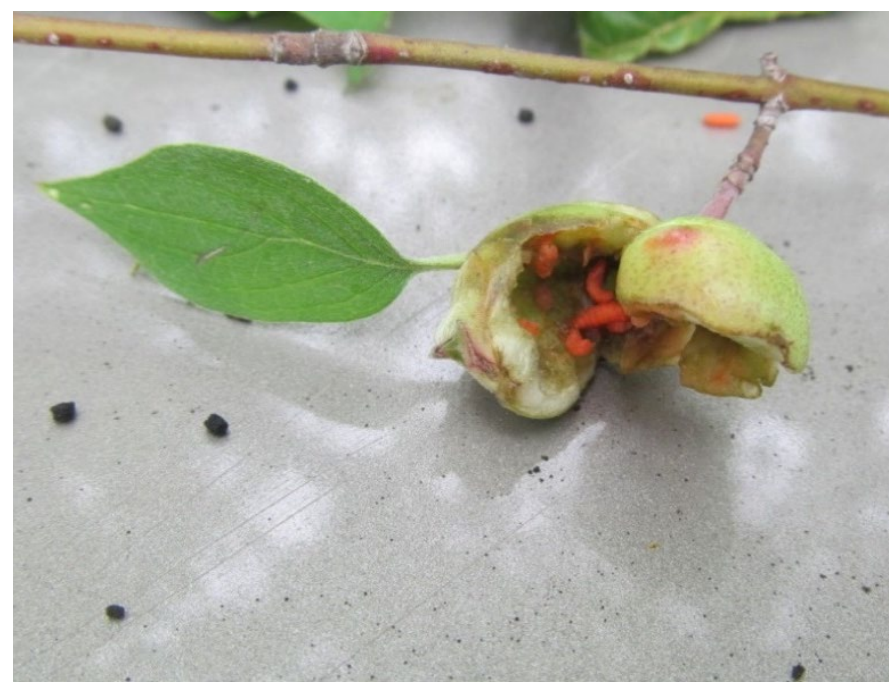

Figure 21 Roughleaf dogwood, Cornus drummondii. Note the straight stems and the orange larvae in a stem gall.

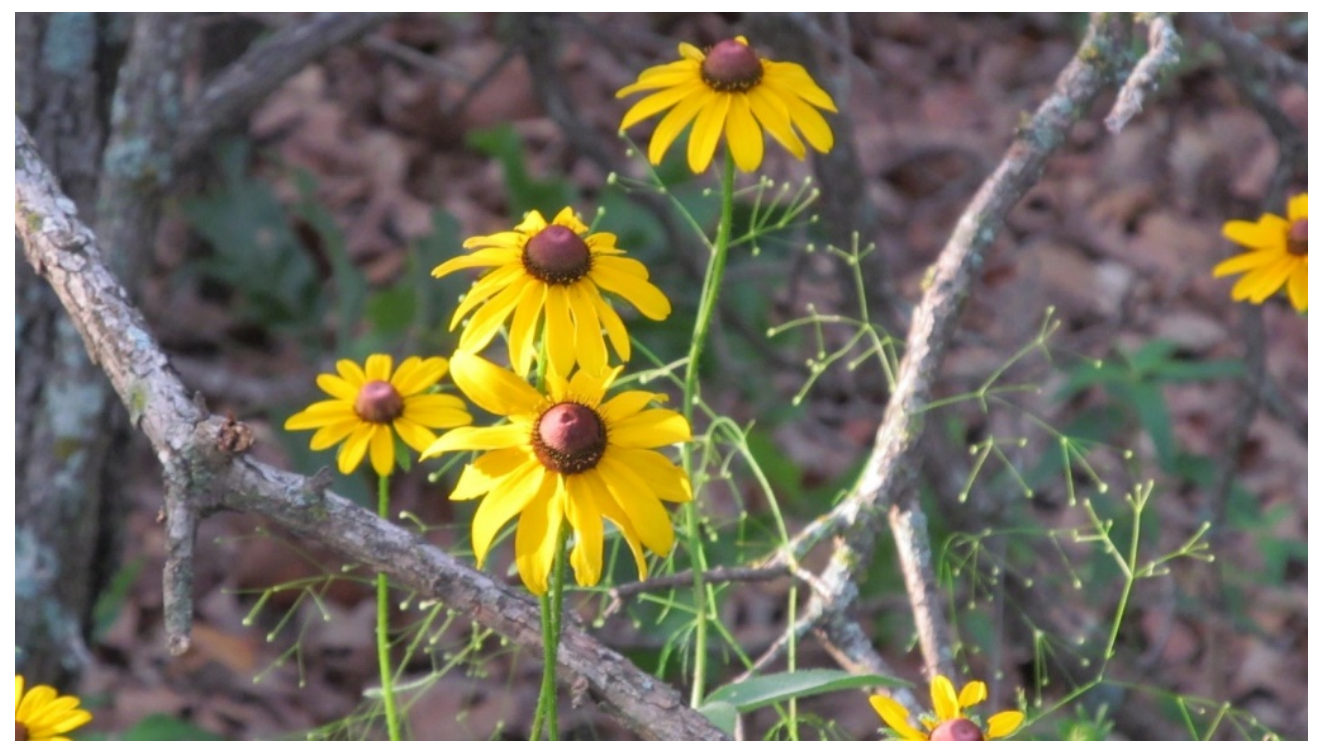

Figure 22 Brown-eyed susan, Rudbeckia in June. We have not recorded all the herbaceous plants in the forest. There are several wildflowers and grasses that we need to document.

Landmark 8. The Drain. As you continue your walk, you will see a low-lying area that we call the "drain" (Figure 23). You cannot miss seeing a large dead post oak leaning on other oak trees. Walking west through the drain you will see a yaupon holly, Ilex vomitoria, on your left and a small population of pricklyash, Zanthoxylum americanum, on the right side. Pricklyash has oddpinnately compound leaves with sharp prickles. If you break a leaflet from the pricklyash, you should smell the citrus aromatic compounds. Go ahead and bite the leaflet and taste it on the tip of your tongue. What do you taste? As you continue your walk west along the trail, you should see several small chinquapin oak trees, Quercus mueblenbergii. We have not seen any large trees in the forest of this species. Also, near the drain you might see some dog vomit slime mold on a tree stump (Figure 24). 


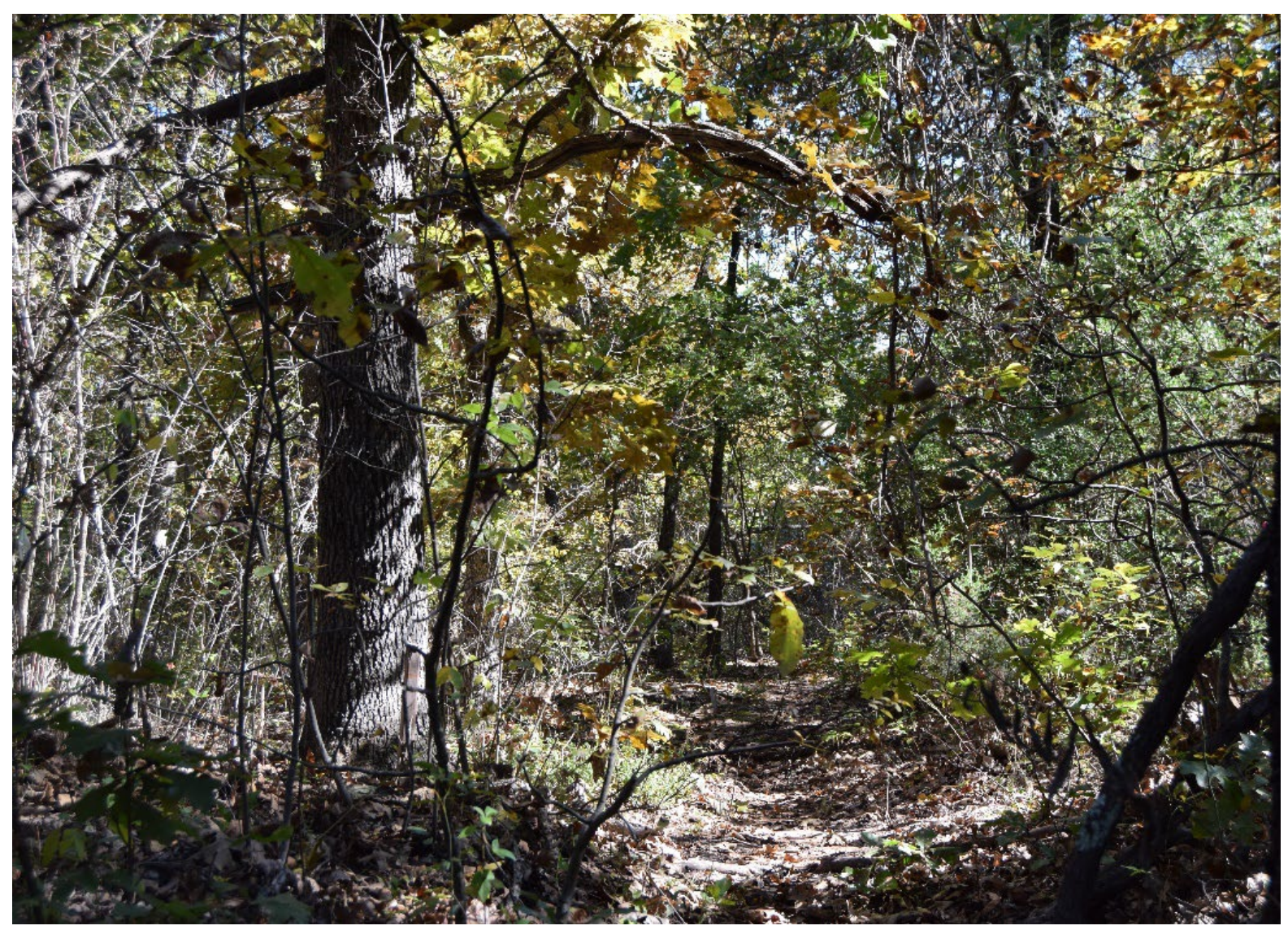

Figure 23 The “drain.” Photo by Riley Tollers.

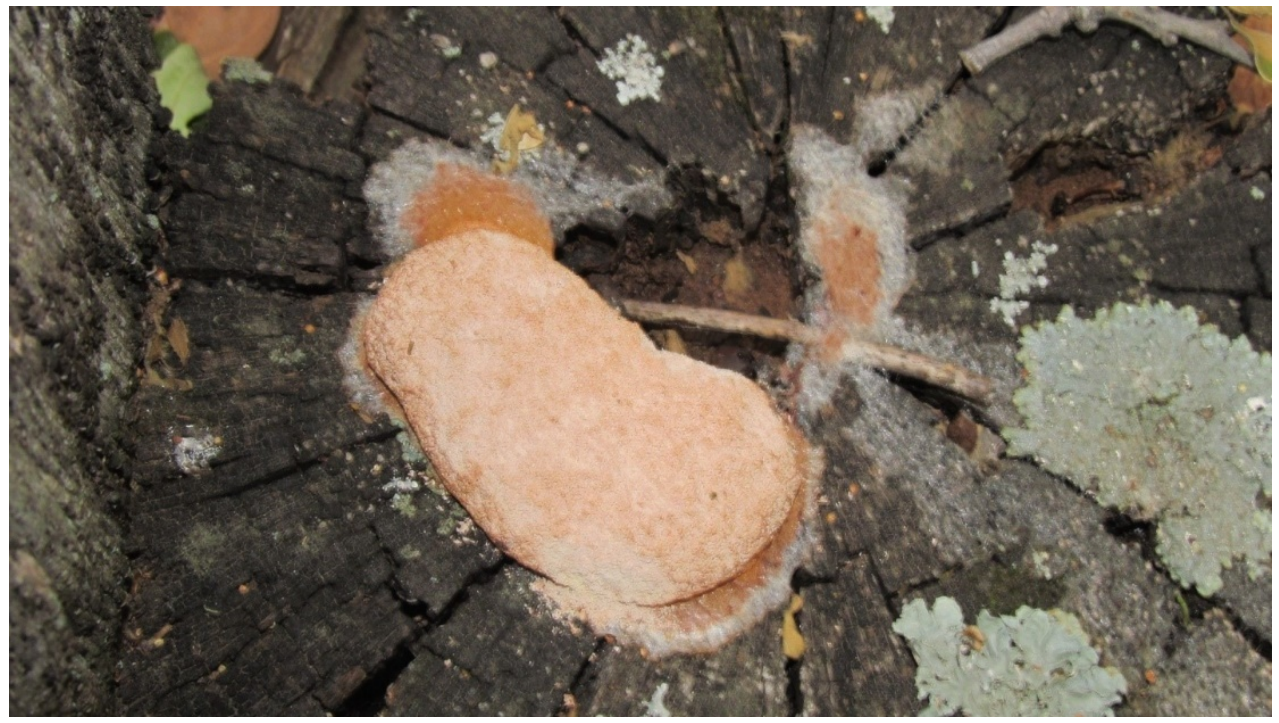

Figure 24 Dog vomit slime mold on a tree stump near the "drain"

Landmark 9. Redbud. As you enter the "drain" from the east side, look on the right and you will see an open area with at least one redbud tree, Cercis canadensis. 
Landmark 10. Red mulberry. Walking west out of the drain you will find two red mulberry trees, Morus rubra. Note the understory growth habit of these trees, their distinctive bark (Figure 25), and their large ovate leaves with acuminate apices (Figure 26).

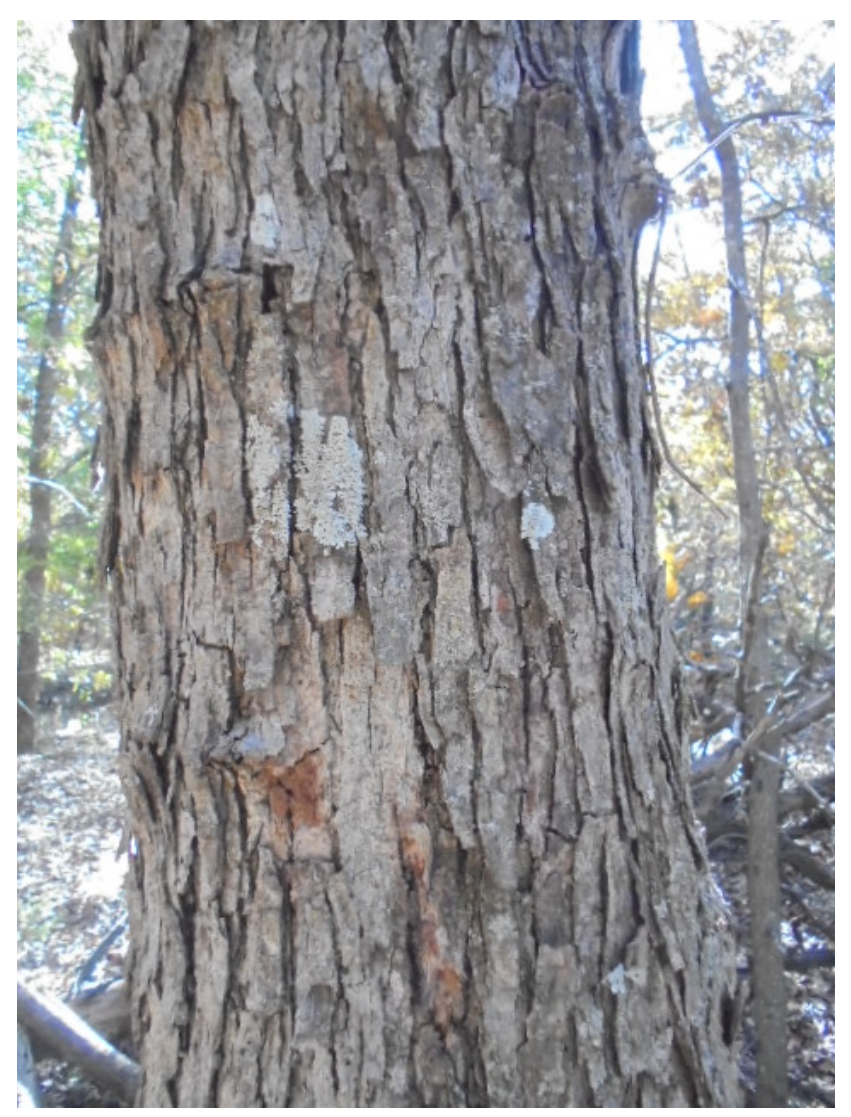

Figure 25 Red mulberry bark. The bark has long light brown plates that flare up at the ends. With repeated visits to the forest you should recognize these trees by their bark.

Figure 26 Red mulberry, Morus rubra, tree under the canopy. Note the large leaves for collecting sunlight and the acuminate blade apices.

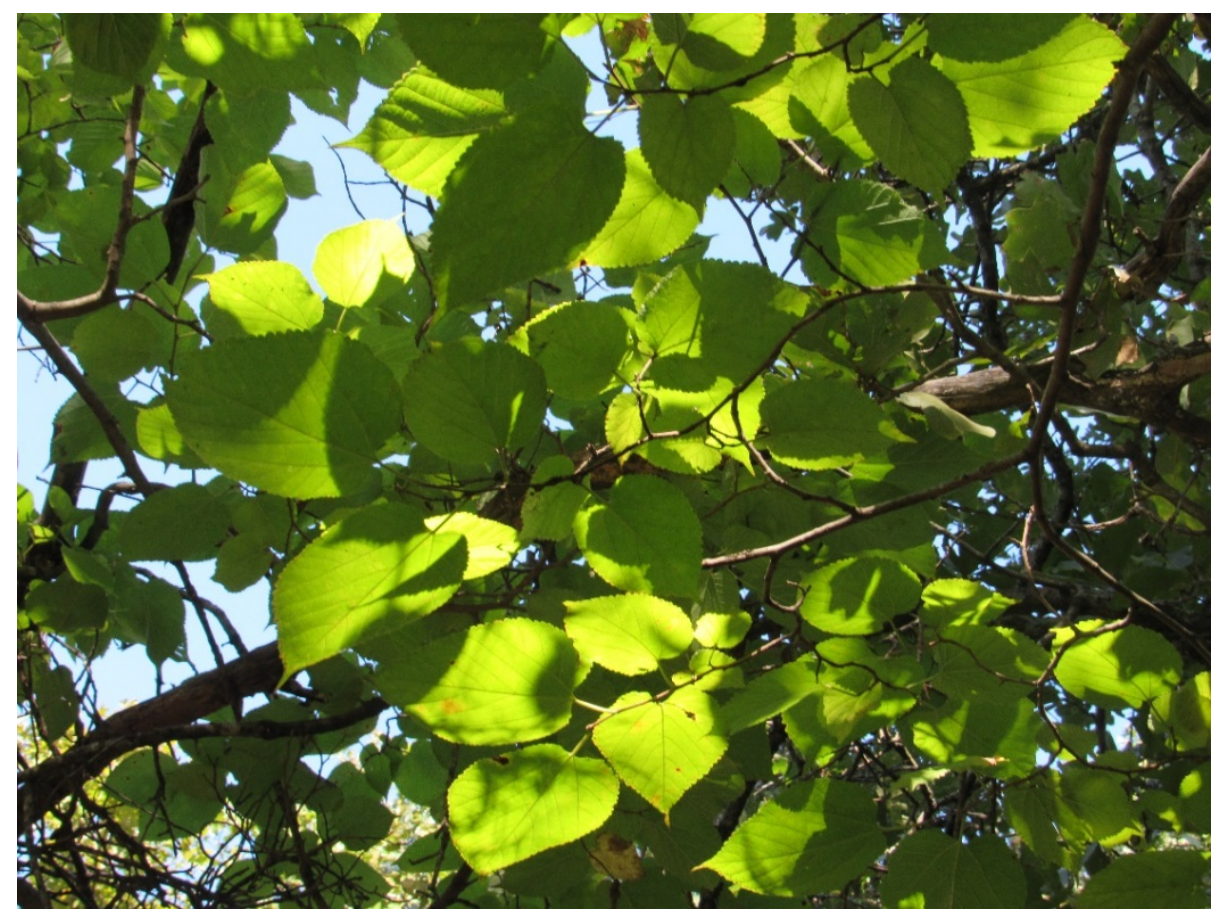

Bruce A. Smith 
Landmark 11. Big post oak, Quercus stellata. Turning north and slightly west you will see a large old post oak tree (Figures 27 and 28). Post oak trees are the most frequent, have the highest density, and have the greatest basal area of any tree in the forest. In order to positively identify post oak trees use Table 3 .

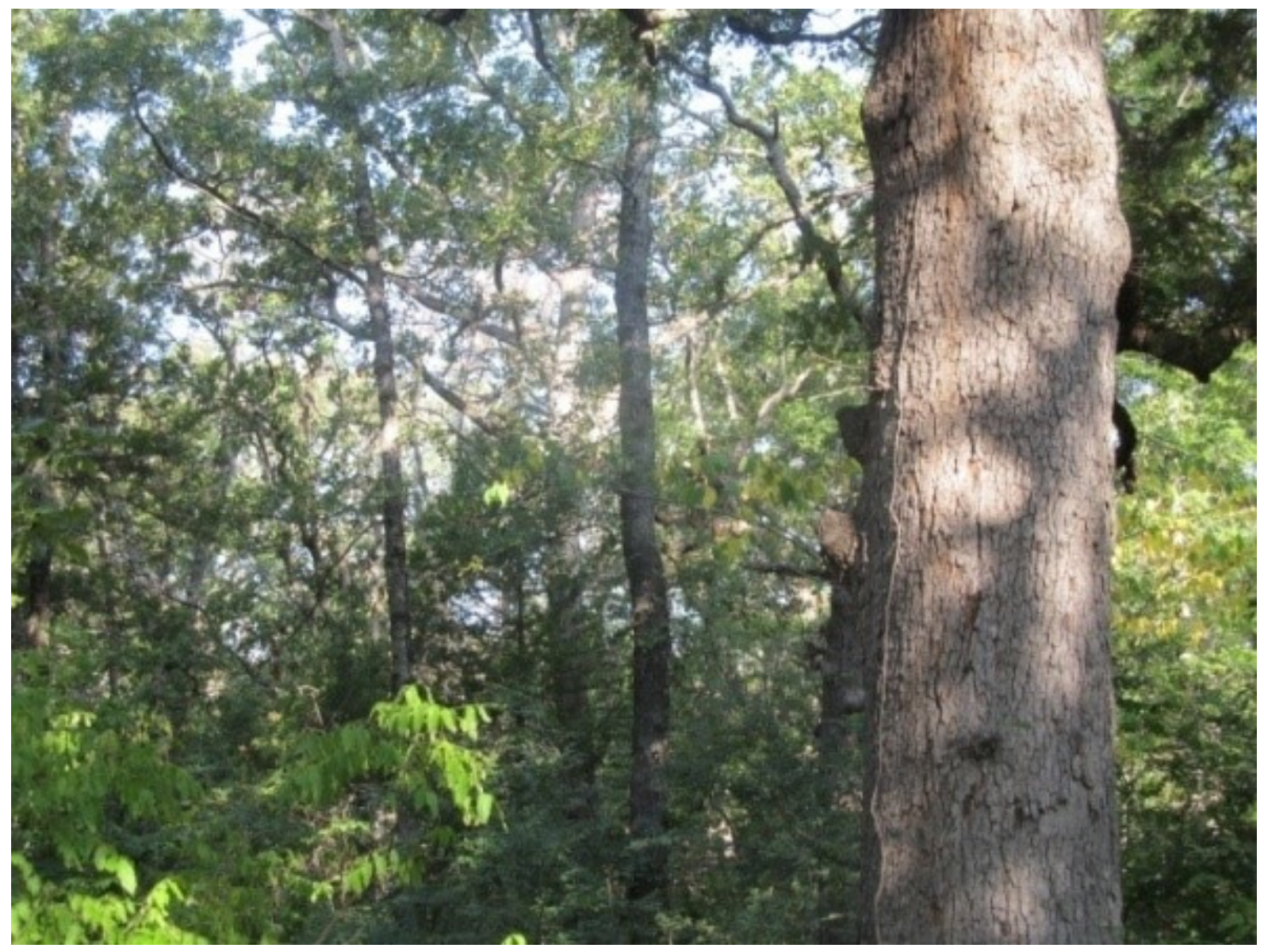

Figure 27 Quercus stellata, post oak 
Table 3 Diagnostic characters to used identify post oak, Quercus stellata

\begin{tabular}{|l|l|}
\hline Characteristics & Description \\
\hline Associated species & $\begin{array}{l}\text { Blackjack oak, coralberry, and black } \\
\text { hickory }\end{array}$ \\
\hline Terminal buds & Oaks have multiple terminal buds \\
\hline Leaf arrangement & Alternate, with one leaf per node \\
\hline Blade complexity & Simple \\
\hline Blade shape & $\begin{array}{l}\text { Obovate with lateral rounded lobes. } \\
\text { The leaves are often described as } \\
\text { cross-like. }\end{array}$ \\
\hline Awns & $\begin{array}{l}\text { Absent; post oaks are part of the } \\
\text { subgenus of oaks known as } \\
\text { Leucobalanus }\end{array}$ \\
\hline Abaxial surfaces of blades & Stellate or star-like hairs \\
\hline Bark & $\begin{array}{l}\text { Light brown with long narrow plates } \\
\text { (see Figure 28) }\end{array}$ \\
\hline DBH & $\begin{array}{l}\text { Post oaks in the MHS forest are the } \\
\text { trees (other than black hickory) that } \\
\text { have large diameters. }\end{array}$ \\
\hline
\end{tabular}

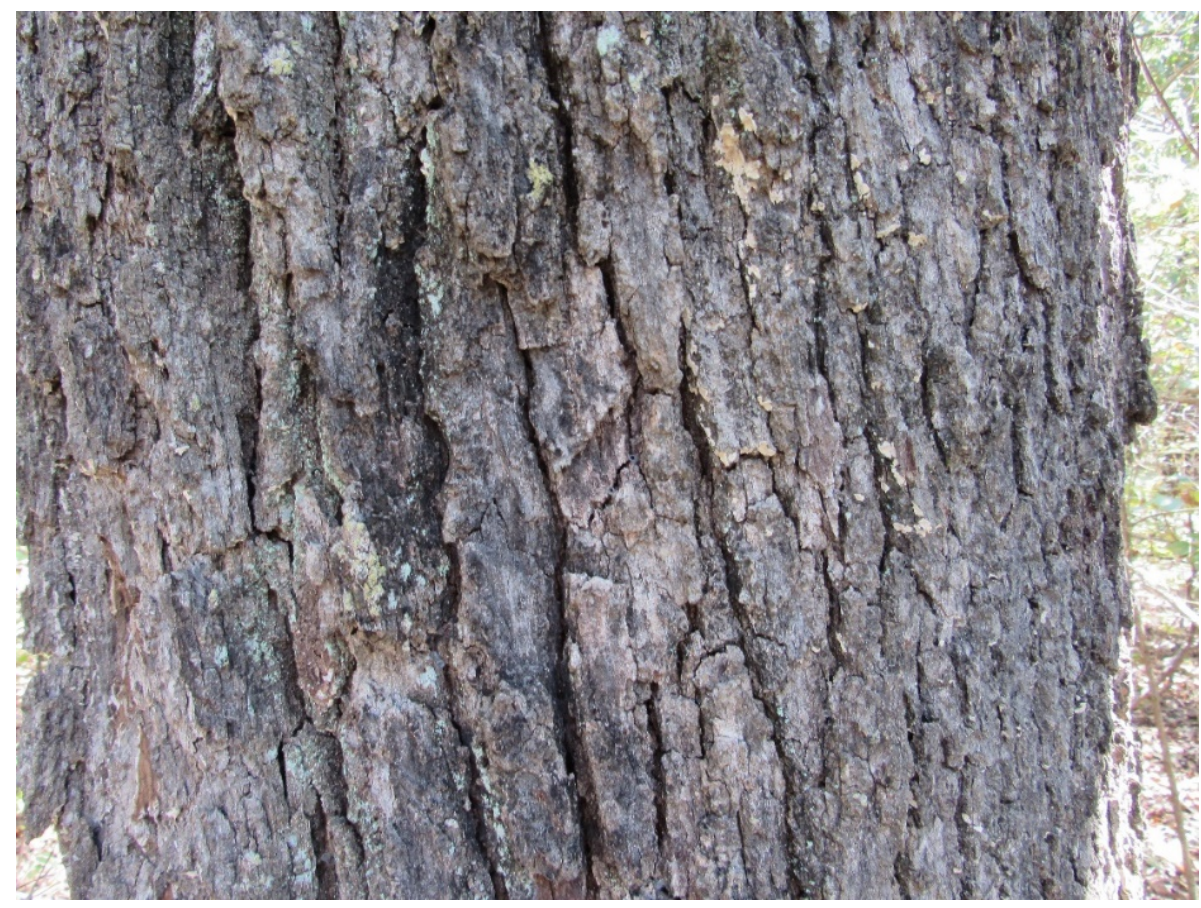

Figure 28 Post oak bark. Note the elongated light brown plates. 
Landmark 12. Twin Oaks. These two old post oak trees are by far the most visited landmarks in the forest. Both are approximately $60 \mathrm{~cm}$ in diameter at breast height. The tree on the left side (Figure 29) has experienced some bark damage. Hopefully we will see no change in its vigor this spring.

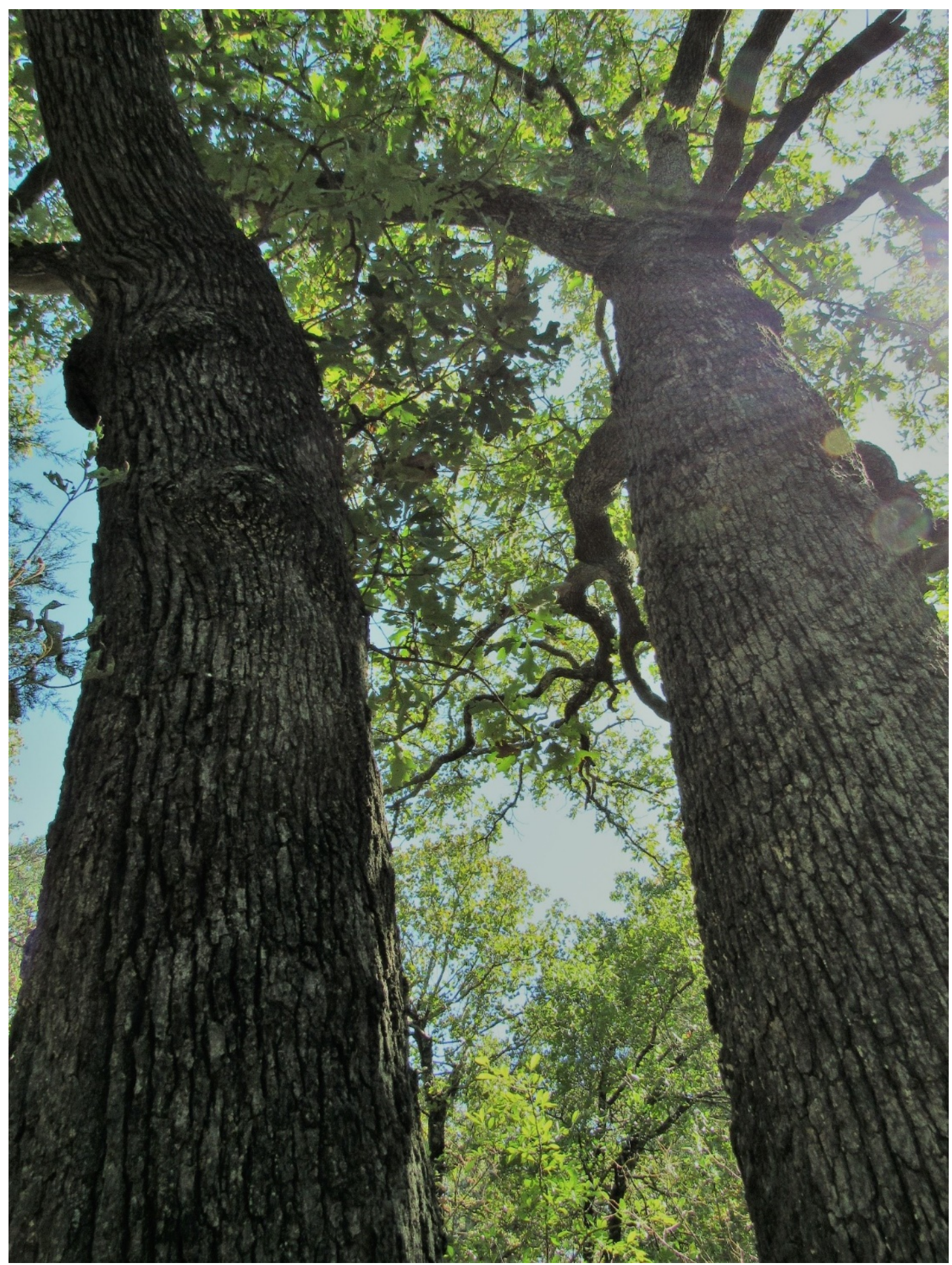

Figure 29 Twin oaks, two old post oaks, Quercus stellata 
Landmark 13. Mulberry-oak center. Walking north and slightly east you will see a large post oak and red mulberry growing together (Figure 30). Just a few meters north of these two trees you will find a Mexican plum, Prunus mexicana. Keep an eye out for this tree and other individuals of the species. In late winter and early spring, they will light up the forest with white blooms in an otherwise barren forest. Spring is coming.

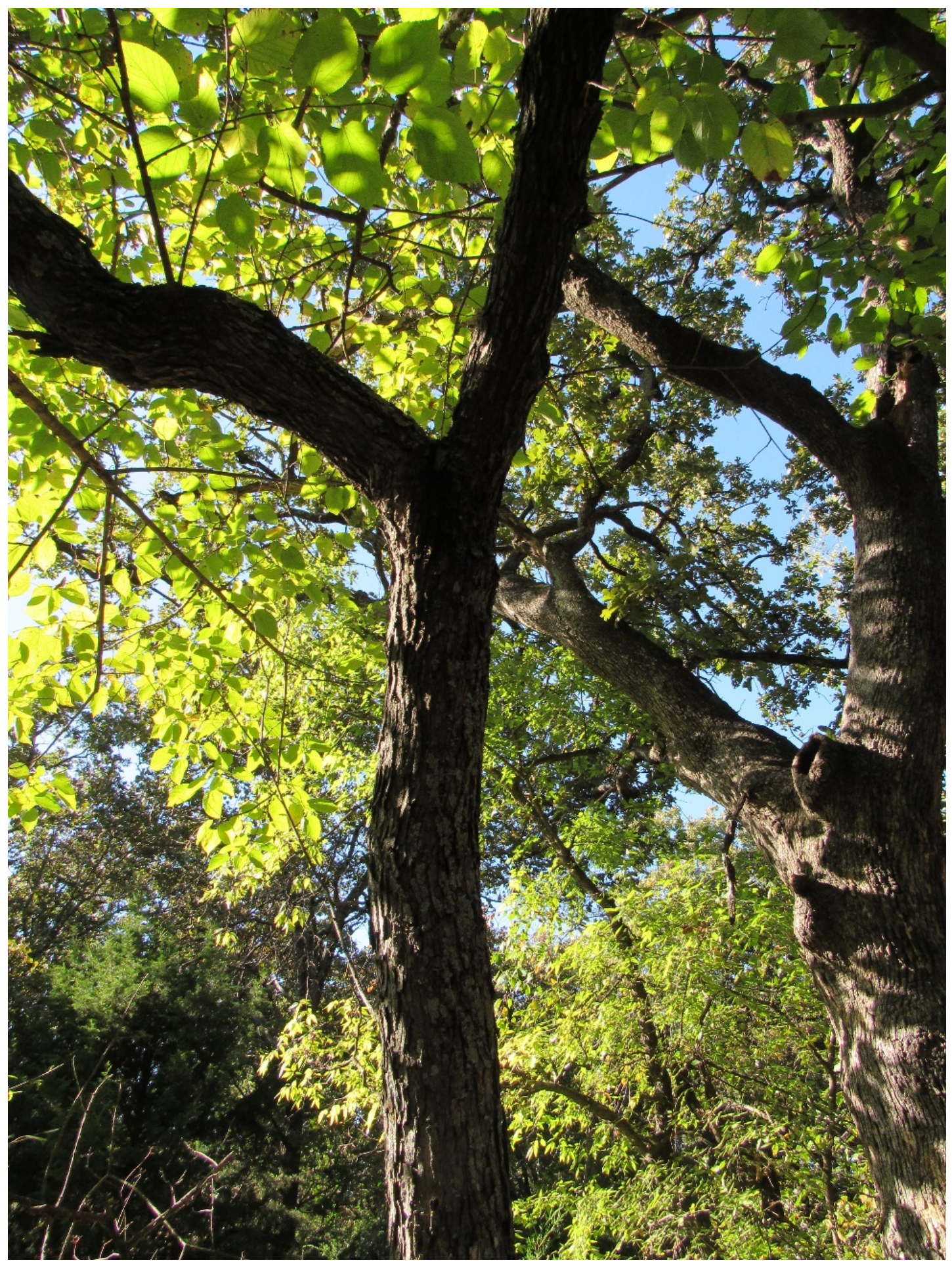

Figure 30 Red mulberry (left) and post oak (right) 
Landmark 14. Bent blackjack oak, Quercus marilandica. Traveling north and east you will see a blackjack oak that is noticeably bent (Figure 31). What caused it to bend? In the same area in the fall you might find a big bluestem grass, Andropogon gerardii.

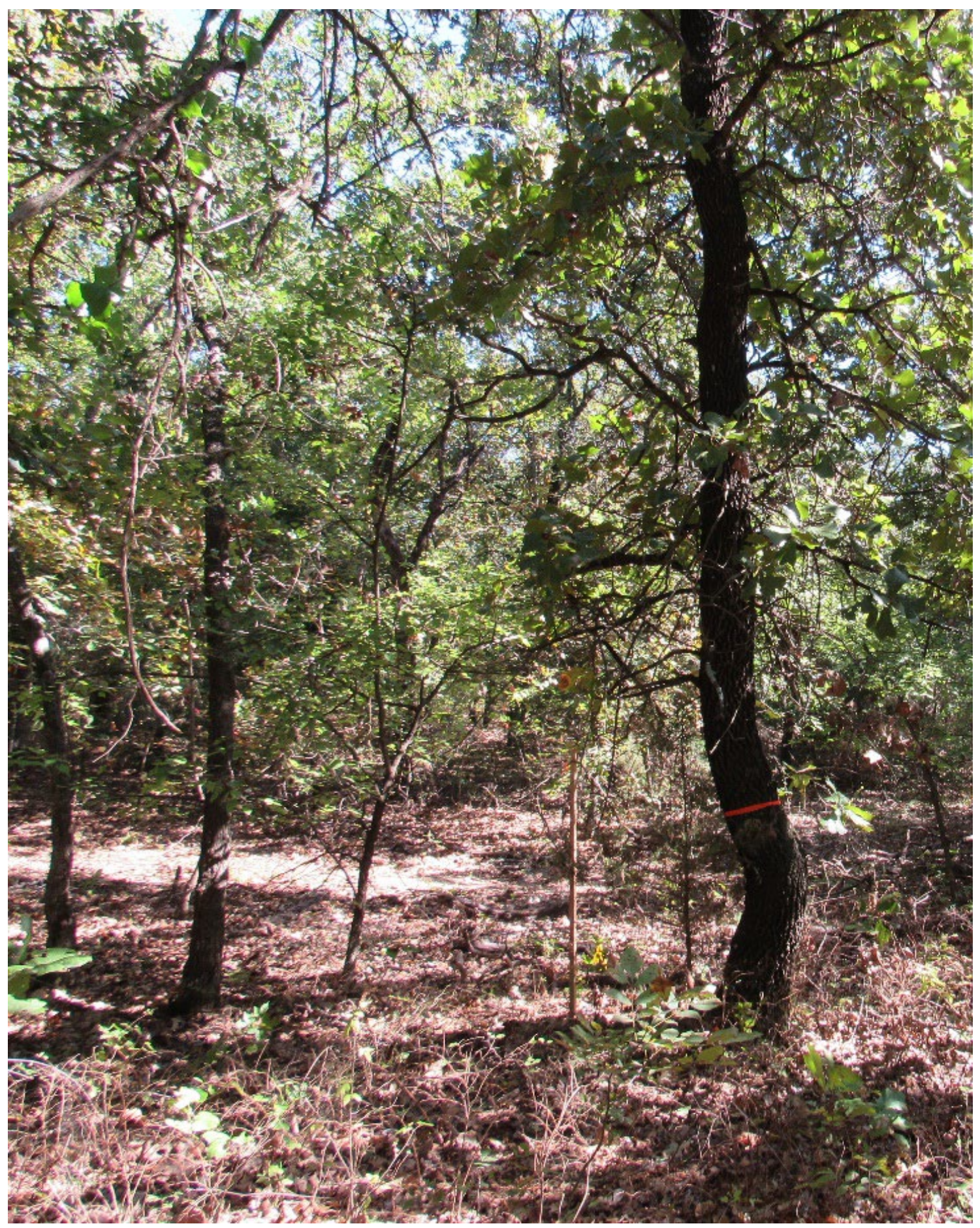

Figure 31 Bent blackjack oak, Quercus marilandica

Landmark 15. American elm, Ulmus americana. This is the second elm in the forest. If you have a $10 \mathrm{x}$ hand lens you can see the glabrous axillary buds. 
Landmark 16. Black oak. You are almost finished with your walk. The last stop is a black oak, Quercus velutina (Figures 32 and 33). This oak species is common throughout the forest. They are frequent, but not large. The largest black oak tree that we have seen is only about $9 \mathrm{~cm}$ at breast height; compared to some of the post oak and black hickory, they are relatively small. For a comparison, Table 4 gives diameter at breast height (dbh) measurements for trees at the landmarks in this forest. In the same area, you might find a small population of western soapberry, Sapindus drummondii. The trees are 1-2 meters tall with slender stems. One way to identify them is by their even-pinnately compound leaves. Even if you visit this area in the winter (Figure 34), you can recognize the woody plants by many of the bark and bud characteristics pointed out in this trail guide.

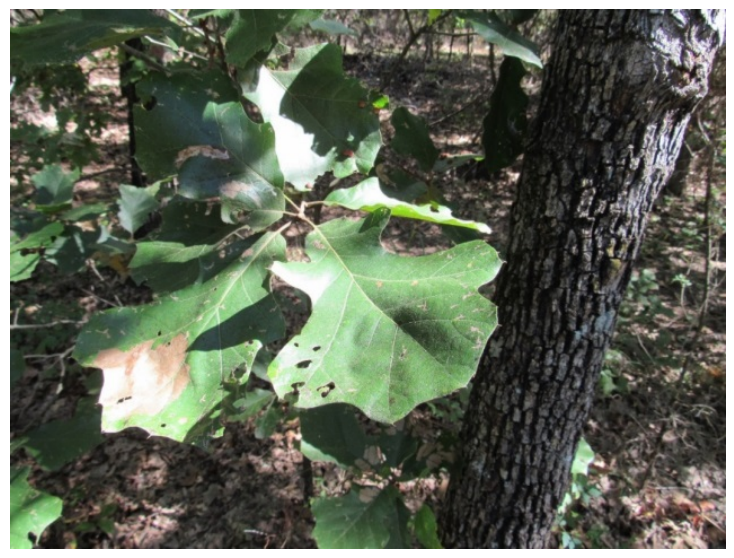

Figure 32 Black oak, Quercus velutina, one of the two red oak species in the forest

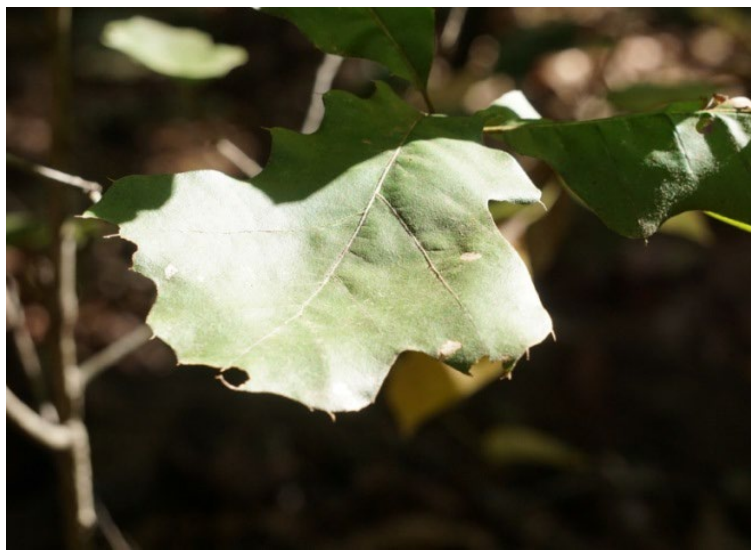

Figure 33 Black oak, Quercus velutina. Note the awns on the tip of the simple leaf. Black oak is classified as a red oak due to leaf awns and other characteristics.

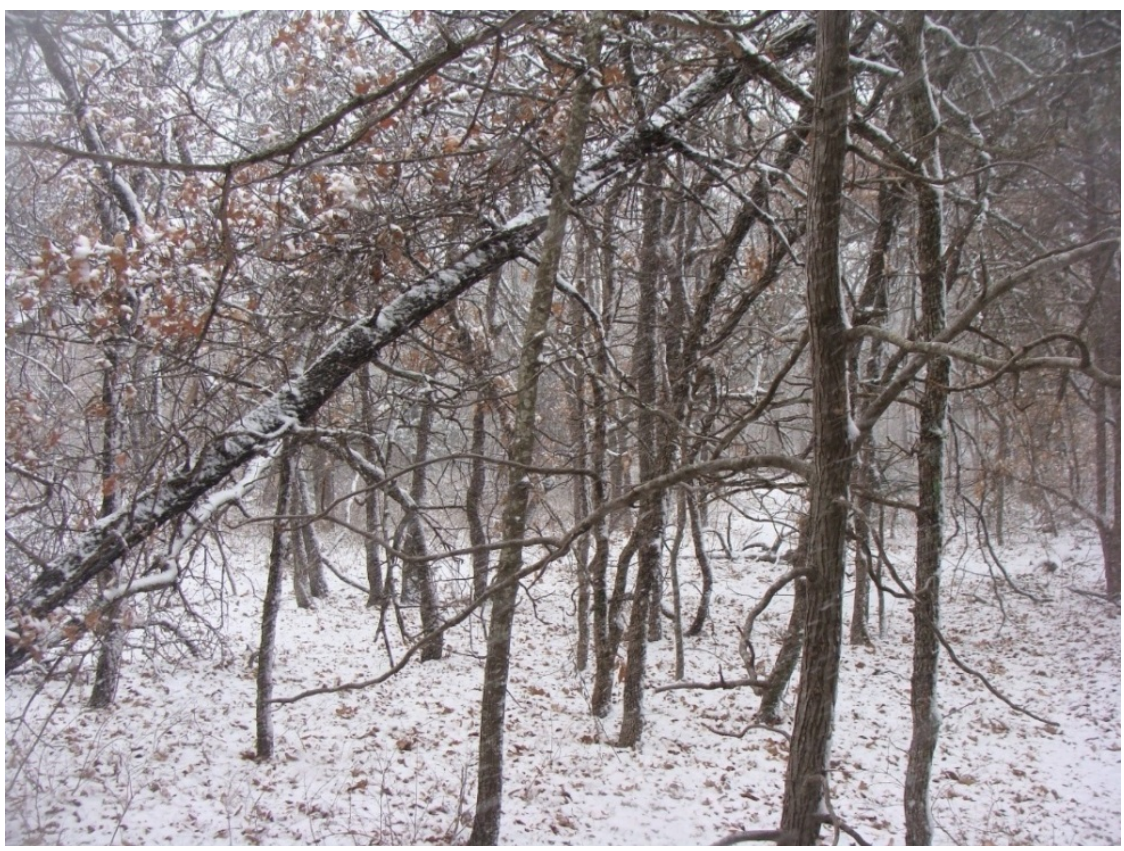

Figure 34 Winter scene taken several years ago in the McLoud oak-hickory forest. 
Table 4 Diameter at breast height (DBH) of key tree species at different landmarks. The diameter of these trees will hopefully give you an idea of the relative size and perhaps the age of some of the trees in the forest. (DBH and age are not always well correlated.)

\begin{tabular}{|c|c|c|}
\hline SITE & TREE (SPECIES) & $\begin{array}{c}\text { DBH (DIAMETER } \\
\text { AT BREAST } \\
\text { HEIGHT) }\end{array}$ \\
\hline 1,2 (Near entrance) & $\begin{array}{l}\text { Red elm, } \\
\text { Ulmus rubra }\end{array}$ & $7 \mathrm{~cm}$ \\
\hline 3,4 (Dead post oak) & $\begin{array}{c}\text { Post oak, } \\
\text { Quercus stellata (dead) }\end{array}$ & $48 \mathrm{~cm}$ \\
\hline 5 (Hackberry) & $\begin{array}{c}\text { Hackberry/Sugarberry, } \\
\text { Celtis sp. }\end{array}$ & $34,25,17$ and $14 \mathrm{~cm}$ \\
\hline 6 (Big hickory forest) & $\begin{array}{l}\text { Black hickory, } \\
\text { Carya texana }\end{array}$ & $50,51,52$ and $57 \mathrm{~cm}$ \\
\hline 7 (Dead cottonwood) & $\begin{array}{l}\text { Cottonwood, Populus } \\
\text { deltoides (dead) }\end{array}$ & $37 \mathrm{~cm}$. \\
\hline 10 (Red mulberry, edge) & $\begin{array}{l}\text { Red mulberry, } \\
\text { Morus rubra }\end{array}$ & 8 and $14.5 \mathrm{~cm}$ \\
\hline 11 (Big post oak) & $\begin{array}{l}\text { Post oak, } \\
\text { Quercus stellata }\end{array}$ & $60 \mathrm{~cm}$ \\
\hline 12 (Twin oaks) & $\begin{array}{l}\text { Post oak, } \\
\text { Quercus stellata }\end{array}$ & 63 and $65 \mathrm{~cm}$ \\
\hline 13 (Mullberry-Oak, center) & $\begin{array}{l}\text { Red mulbery, } \\
\text { Morus rubra, and } \\
\text { Post oak, } \\
\text { Quercus stellata }\end{array}$ & $\begin{array}{l}26 \mathrm{~cm} \text { red mulberry } \\
\text { and } 58 \mathrm{~cm} \text { post oak }\end{array}$ \\
\hline 14 (Bent Blackjack oak) & $\begin{array}{c}\text { Blackjack oak, } \\
\text { Quercus marilandica }\end{array}$ & $30 \mathrm{~cm}$ \\
\hline 15 (American elm, north edge) & $\begin{array}{l}\text { American elm, } \\
\text { Ulmus americana }\end{array}$ & $8 \mathrm{~cm}$ \\
\hline 16 (Black oak, north edge) & $\begin{array}{l}\text { Black oak, } \\
\text { Quercus velutina }\end{array}$ & $9.0 \mathrm{~cm}$ \\
\hline
\end{tabular}

